This item was submitted to Loughborough's Research Repository by the author.

Items in Figshare are protected by copyright, with all rights reserved, unless otherwise indicated.

\title{
The potential of kaolin as a reinforcing filler for rubber composites with new sulfur cure systems
}

\section{PLEASE CITE THE PUBLISHED VERSION}

https://doi.org/10.1177/0731684417712070

\section{PUBLISHER}

SAGE @ The Author(s)

VERSION

AM (Accepted Manuscript)

\section{PUBLISHER STATEMENT}

This work is made available according to the conditions of the Creative Commons Attribution-NonCommercialNoDerivatives 4.0 International (CC BY-NC-ND 4.0) licence. Full details of this licence are available at: https://creativecommons.org/licenses/by-nc-nd/4.0/

\section{LICENCE}

CC BY-NC-ND 4.0

\section{REPOSITORY RECORD}

Sheikh, Saad H., Xuena Yin, Ali Ansarifar, and Keith A. Yendall. 2017. "The Potential of Kaolin as a Reinforcing Filler for Rubber Composites with New Sulfur Cure Systems”. figshare. https://hdl.handle.net/2134/25591. 


\title{
The potential of kaolin as reinforcing filler for rubber composites with new sulfur cure systems
}

\author{
Saad H Sheikh ${ }^{1}$, Xuena Yin ${ }^{1}$, Ali Ansarifar ${ }^{1}$, Keith Yendall ${ }^{2}$ \\ ${ }^{1}$ Materials Department, Loughborough University, UK \\ ${ }^{2}$ Loughborough Materials Characterization Centre, Loughborough University, UK
}

\section{Abstract}

The effect of a large amount of kaolin (China clay) on the viscosity, cure, hardness, Young's modulus, tensile strength, elongation at break, stored energy density at break, tear energy and compression set resistance of some sulfur-cured natural rubber (NR), polybutadiene rubber (BR) and ethylene-propylene-diene rubber (EPDM) composites was investigated. The kaolin surface had been pre-treated with 3-mercaptopropyltrimethoxysilane (MPTS) to improve its dispersion in the rubbers. For NR, the hardness and Young's modulus improved, tensile strength and tear energy were unchanged and the remaining properties deteriorated when kaolin was added. The viscosity increased and the scorch and optimum cure times decreased whilst the cure rate rose with kaolin. For BR and EPDM, with the exception of the compression set resistance, all the properties including the viscosity gained from the kaolin. The kaolin was found to be extending or non-reinforcing filler for NR, and highly reinforcing for BR and EPDM. In addition, the scorch and optimum cure times and cure rate of BR benefitted, whereas with the exception of the scorch time, the optimum cure time and cure rate of EPDM were adversely affected by kaolin.

Corresponding author: A. Ansarifar at M.A.Ansarifar@lboro.ac.uk, Tel: +44 01509-223159 Fax no:+44 01509223949 


\section{Keywords}

Rubber, kaolin, viscosity, cure properties, mechanical properties

\section{Introduction}

Solid fillers and curing chemicals perform two distinct functions in rubber compounds.

Fillers increase the dynamic and mechanical properties ${ }^{1,2}$ and curing chemicals produce crosslinks between the rubber chains at elevated temperatures, i.e., 140$220^{\circ} \mathrm{C}^{3,4}$ Since the discovery of their reinforcing qualities almost 100 years ago, petroleum-based colloidal carbon blacks $(\mathrm{CB})$ have been used extensively in rubber reinforcement. ${ }^{5,6}$ The term reinforcement is defined as the increases in properties such as tensile strength, tear strength, hardness, abrasion resistance and modulus. ${ }^{7}$ Synthetic silicas have been replacing CBs in some applications for example tire tread compound ${ }^{8}$ and proved to be as effective as CBs. However, the surface of silicas possesses siloxane and silanol groups, which make the filler acidic ${ }^{9}$ and moisture adsorbing. ${ }^{10}$ Acidity and moisture are both detrimental to the cure of rubber compounds ${ }^{11}$ and can also cause loss of crosslink density in sulfur-cured rubbers. ${ }^{12}$ Bifunctional organosilanes, known also as coupling agent, remedy the problems aforementioned and are used to enhance the reinforcing capability of silicas in rubber. $^{12}$ Other fillers such as layer silicates ${ }^{13-18}$, carbon nanotubes ${ }^{19-21}$, and exfoliated graphene ${ }^{22,23}$ have been intensively researched as a potential reinforcing agent in rubber. Several examples of reviews ${ }^{24-27}$ suggest that the nanofillers mentioned above are a promising reinforcing agent to improve mechanical and dynamic properties of rubber particularly at low filler loading. Among the fillers, hydrous aluminium phyllosilicates or clay minerals such as montmorillonite (MMT) and kaolin have received much attention in recent years because they are relatively 
inexpensive and also non-carcinogenic. Since MMT consists of a triple-layer sandwich structure, hence its dispersion mechanism in rubber is different from carbon black and silica which have a spherical shape ${ }^{28}$ As reported in literature ${ }^{28-32}$ intercalation and exfoliation morphologies are used to characterise the clay layer dispersion in clay/polymer nanocomposites. The latter morphology is more desirable due to its high surface area, which is important in rubber reinforcement. Nevertheless, producing a high level of clay dispersion in rubber is still a challenge.

Several studies have looked into potential replacement of CB and silica with kaolin. Similar to silica, the kaolin surface possesses $\mathrm{OH}$ groups, which makes it polar and moisture adsorbing. To improve dispersion of the kaolin particles in rubber, the filler surface is often treated with silane.$^{33}$ Previous studies where kaolin was used in natural rubber (NR) showed promising results. For example, in a study small amount of kaolin, i.e. $10 \mathrm{phr}$, was modified with sodium salt of rubber seed oil (SRSO) and mixed with NR. ${ }^{34}$ The rubber filled with SRSO-modified kaolin cured faster than that of a similar mix containing unmodified kaolin. In addition, the NR composites containing SRSO-modified kaolin showed considerable increases in tensile modulus, tensile strength, and elongation at break. This indicated kaolin potential as an organo-modified nanofiller.

In a study, importance of the surface organo-modification of kaolin was demonstrated. ${ }^{35}$ Metal salt of rubber seed oil (RSO-Na) was used to modify kaolin and then was introduced into NR. Rubber composites mixed with various compositions of pristine and modified kaolin (2-10 phr) were then prepared and tested. The results showed that the modified kaolin improved the cure and mechanical properties of the rubber composite compared to the pristine kaolin-filled rubber. For example, the viscosity and hardness increased with increase in filler 
concentration. Furthermore, the extent of crosslink density and rubber-filler interaction also improved. It was concluded that the presence of the modified kaolin resulted in the formation of a higher number of crosslinks, which was attributed to the confinement of the rubber chains within the silicate galleries and consequently, to better interaction between the filler and the rubber.

Typical rubber formulation for commercial products such as NR-based conveyor belt cover consists of up to eleven different chemical additives including cure system and reinforcing filler. The cure system is made of sulfur, three accelerators (primary and secondary), and primary and secondary activators (zinc oxide and stearic acid), respectively), adding up to 9.7 parts per hundred rubber (phr) by weight. ${ }^{36}$ The reinforcing filler is carbon black (CB) ${ }^{36}$ In any rubber formulation, chemical curatives and solid fillers are indispensable. The former provides shape stability and the latter, reinforcement of the dynamic and mechanical properties of the cured rubber, which is essential for the performance, durability and life of the final product in service. ${ }^{37-38}$

Excessive use of the chemical curatives is harmful to health, safety, and the environment. According to the European Directive 67/548/EEC, zinc oxide is very toxic to aquatic organisms. Stearic acid causes skin and eye irritation and is classified as highly flammable. ${ }^{39}$ Both of these chemicals are used extensively as activator in sulfur vulcanization. ${ }^{36} \& 40$ Besides, CBs could be highly toxic and pose a considerable health risk associated with their use in rubber compounds. ${ }^{41}$ There is a need to replace CB with less harmful solid fillers.

The aim of this study was to investigate effect of up to $140 \mathrm{phr}$ of kaolin modified with a mercaptosilane on the viscosity, cure and mechanical properties of some commercially important rubber composites. The study used a new method for 
measuring the exact amount of the chemical curatives required in the sulfur vulcanization of the rubbers. The idea was to substantially reduce the usage of these harmful chemicals and replace toxic carbon black and silica/silane filler systems with the much safer mineral kaolin.

\section{Experimental}

\section{Materials and mixing}

The raw rubbers used were standard Malaysian natural rubber (NR) grade L (98wt\%1,4-cis content; SMRL); high cis polybutadiene rubber (96wt\% 1,4-cis content; Buna CB24, Bayer, Newbury, UK; not oil extended); ethylene-propylene-diene rubber (EPDM; 48wt\% ethylene content, 9wt\% ethylidene norbornene content, and $13 w t \%$ oil content, Keltan 6251A, Lanxess, The Netherlands). The reinforcing filler was Mercap 100 (Imerys Ceramics, USA). Mercap 100 is kaolin (China clay; $\left.\mathrm{Al}_{2} \mathrm{Si}_{2} \mathrm{O}_{5}(\mathrm{OH})_{4}\right)$, the surface of which had been pre-treated with 3-mercaptopropyltrimethoxysilane (MPTS) to reduce its polarity and prevent it from adsorbing moisture. As mentioned earlier, surface polarity and moisture are detrimental to the dispersion of filler particles in rubber and sulfur vulcanization of rubber compounds. ${ }^{9-12}$ MPTS contains less than $2 \mathrm{wt} \%$ of sulfur. Mercap 100 has a very fine particle size of about 0.3 micron and $25 \mathrm{~m}^{2} / \mathrm{g}$ surface area measured by nitrogen adsorption (Imerys Ceramics, USA). It contains approximately 90 parts per million (ppm) of sulfur, which primarily comes from trace secondary minerals, mainly pyrite $\left(\mathrm{FeS}_{2}\right)$ with a melting point of $1,100^{\circ} \mathrm{C}$. The kaolin was supplied in a plastic bag. The powder was placed in an oven at $80^{\circ} \mathrm{C}$ for at least $48 \mathrm{~h}$ to remove moisture if any before mixing it with the rubbers. 
In addition to the raw rubbers and kaolin, the other ingredients were elemental sulfur (curing agent, Solvay Barium Strontium, Hannover, Germany), N-tert-butyl-2benzothiazole sulfenamide (a fast-curing delayed-action accelerator with a melting point of $105^{\circ} \mathrm{C}$, Santocure TBBS, Sovereign Chemicals, USA), zinc oxide (ZnO, an activator, Harcros Durham Chemicals, Durham, UK), stearic acid (an activator, Anchor Chemicals Ltd, UK); and N-(1,3-dimethylbutyl)-N'-phenyl-p-phenylenediamine (6PPD) (an antidegradant with a melting point of $45-51^{\circ} \mathrm{C}$, Santoflex 13 , Brussels, Belgium).

The raw rubbers were mixed with the chemical ingredients in a Haake Rheocord 90 (Berlin, Germany), a small laboratory mixer with counter-rotating rotors, to produce compounds. The Banbury rotors and the mixing chamber were initially set at ambient temperature $\left(23^{\circ} \mathrm{C}\right)$ and the rotor speed was set at $45 \mathrm{rpm}$. The volume of the mixing chamber was $78 \mathrm{~cm}^{3}$ and it was $60 \%$ full during mixing. Polylab monitor 4.17 software was used for controlling the mixing condition and storing data. To prepare the unfilled NR, BR and EPDM compounds, the raw rubber was introduced first into the mixer and mixed for $1 \mathrm{~min}$ and then sulfur, TBBS, $\mathrm{ZnO}$, stearic acid and antidegradant were added and mixed for another $12 \mathrm{~min}$. A similar procedure was used for making the kaolin-filled compounds where kaolin was added 3 min after mixing started. The temperature of the compounds during mixing was 58$62^{\circ} \mathrm{C}$

Determination of the optimum amount of the chemical curatives in the sulfur-filled $N R$, BR and EPDM rubbers

Sulfur is used extensively in the vulcanization of a wide range of industrial rubber articles. For example, the cure system in NR-based tyre belt skim compound has 5 $\mathrm{phr}^{42}$, in SBR/BR-based compound for footwear $2 \mathrm{phr}^{43}$, and in EPDM-based 
general gaskets 1 phr of sulfur. ${ }^{44}$ In this study, the NR had 1 and 4 phr, BR 0.5 and 1 phr, and EPDM 1 phr of sulfur. To react the sulfur with the rubber to form crosslinks, TBBS was added. The loading of TBBS was raised from 0.25 to $4.5 \mathrm{phr}$ and forty seven compounds were made. Zinc oxide was used as primary activator to improve the effectiveness of TBBS during curing. The loading of $\mathrm{ZnO}$ in the rubbers with sulfur and TBBS was increased from 0 to $0.5 \mathrm{phr}$ and forty four compounds were mixed. To evaluate effect of stearic acid (used as secondary activator with $\mathrm{ZnO}$ ) on the cure properties of the rubbers with sulfur, TBBS and $\mathrm{ZnO}$, twenty two compounds were prepared. The loading of stearic acid was raised from 0 to $2.5 \mathrm{phr}$ to measure the amount needed to improve efficiency of the cure systems.

Viscosity, cure properties, hardness, tensile properties, tear energy and compression set of the rubber vulcanizates

The viscosity, cure properties, hardness, tensile properties and tear energy of the rubbers were measured according to the procedures described in the British Standards.

- Viscosity: British Standard 1673, Part 3 (1969), using a Mooney viscometer (Wallace Instruments, Surrey, UK) and the results were expressed as Mooney Units (MU).

- Cure properties: British Standard 1673: Part 10 (1977), using oscillating disc rheometer curemeter (ODR, Monsanto, Swindon, UK) at $160 \pm 2^{\circ} \mathrm{C}$. From the cure traces (Figure 1), scorch time, $\mathrm{ts}_{2}$, which is the time for the onset of cure, and the optimum cure time, $t_{95}$, which is the time for the completion of cure were determined. $\Delta$ Torque which is the difference between the maximum and minimum torque values on the cure trace of a compound and is an indication of crosslink density changes in the rubber ${ }^{45}$ was also measured. $\Delta$ torque was afterwards 
plotted against the loading of TBBS, $\mathrm{ZnO}$, and stearic acid.

- Cure rate index (CRI): British Standard 903: Part A60: Section 60.1. (1996). CRI is an indication of the rate of cure in the rubber.

- Hardness: British Standard 903: Part A26 (1995), using cylindrical samples $6 \mathrm{~mm}$ thick and $15 \mathrm{~mm}$ in diameter, in a Shore A Durometer hardness tester (The Shore Instrument \& MFG, Co., New York). The test temperature was $23.5^{\circ} \mathrm{C}$.

- Tensile stress-strain properties (tensile strength, elongation at break, stored energy at break and Young's modulus: British Standard 903: Part A2 (1995), in a LR50K plus materials testing machine (Lloyd Instrument, UK), using standard dumbbell test pieces. Lloyd Nexygen 4.5.1. was used to process and store the data. The test temperature was $22^{\circ} \mathrm{C}$ and the crosshead speed was set at 100 $\mathrm{mm} / \mathrm{min}$.

- Tear energy: British Standard 903: Part A3 (1995), in a LR50K plus materials testing machine (Lloyd Instruments, UK), using trouser test pieces. The test temperature was at ambient $\left(23^{\circ} \mathrm{C}\right)$, tear angle $180^{\circ}$, and crosshead speed was set at $50 \mathrm{~mm} / \mathrm{min}$.

- Compression set: British Standard 903: Part A6 (1992), in circular steel compression set jig, $210 \mathrm{~mm}$ in diameter, at $25 \%$ compression for $24 \mathrm{~h}$ at $70^{\circ} \mathrm{C}$, using cylindrical samples $6 \mathrm{~mm}$ thick and $15 \mathrm{~mm}$ in diameter. At the end of each test, the sample was removed and allowed to cool down at room temperature $\left(20^{\circ} \mathrm{C}\right)$ for $30 \mathrm{~min}$ before the set was measured.

\section{Glass transition temperature of the rubber composites}

$\operatorname{Tan} \delta$ is the ratio between loss modulus and elastic modulus. The loss modulus represents the viscous component of modulus and includes all the energy dissipation processes during dynamic strain. The loss modulus, storage modulus and tan $\delta$ were measured in DMAQ800 model CFL-50 (TA Instruments, USA), using Universal 
Analysis 2000 Software Version 4.3A. Test pieces $35 \mathrm{~mm}$ long, $10 \mathrm{~mm}$ wide and approximately $2.8 \mathrm{~mm}$ thick were used. The tests were performed at $1 \mathrm{~Hz}$ frequency. The samples were deflected $256 \mu \mathrm{m}$ (nominal peak to peak displacement) during the test, and the sample temperature was raised from $-130^{\circ} \mathrm{C}$ to $30^{\circ} \mathrm{C}$ at $3^{\circ} \mathrm{C} / \mathrm{min}$ steps. The measurements were repeated to ensure reproducibility of the results. The glass transition temperature of the rubber composites was subsequently determined from the peak values on the $\tan \delta$ vs temperature traces (Figure 2).

\section{Swelling tests in solvent}

The organic solvent used for the swelling tests was a laboratory reagent grade Toluene (Fisher Scientific, UK). In these tests, approximately $1.5 \mathrm{~g}$ of rubber was placed in $60 \mathrm{ml}$ of the solvent in labelled bottles and allowed to swell for 50 days at $20^{\circ} \mathrm{C}$. The weight of the sample was measured every day until it reached equilibrium. The mass of the rubber in the kaolin-filled sample was calculated before it was placed in the solvent. Increase in the weight of the sample in the solvent was attributed to the swelling of the rubber phase. This excluded the dilution effect of the unswellable rigid kaolin from the measurements. The degree of swelling or solvent intake of the rubber in percentage was calculated, using the following expression:

$$
\text { Degree of swelling }=\frac{W s r-W d r}{W d r} \times 100
$$

where $W_{\mathrm{Sr}}$ is the weight of the swollen rubber and $\mathrm{W}_{\mathrm{dr}}$ the weight of the dry rubber in the sample.

$X$-ray diffraction analysis of the kaolin powder and internal structure of the NR composites

The X-ray diffraction (XRD) patterns of the layered kaolin and NR composites (compounds 1-3; Table 1) were produced on a Bruker D2 diffractometer (Bruker, 
Germany). The diffractometer was equipped with $\mathrm{Cu}$ Ka radiation $(\lambda=0.15418 \mathrm{~nm})$, $10 \mathrm{~mA}$ of current and $30 \mathrm{kV}$ of voltage. A minimum of $3 \mathrm{~g}$ of dried kaolin powder was used to carry out the X-ray analysis of the mineral clay. Square flat sheets, $20 \mathrm{~mm}$ by $20 \mathrm{~mm}$ and $2.8 \mathrm{~mm}$ thick, of the cured rubbers were used for the X-ray analysis of the NR composites. The experiment was performed at low angle in the range $2 \theta=1-10^{\circ} \mathrm{C}$ with the scan rate of $0.02 \%$. In addition, the spacing between the structural layers of the kaolin was measured according to the Bragg's law (eq. (2)),

$$
\mathrm{n} \lambda=2 \mathrm{~d} \sin \theta
$$

where $\mathrm{n}$ is an integer, $\lambda$ is the $\mathrm{X}$-ray wavelength, $\mathrm{d}$ is the interlayer spacing, and $\theta$ is the angle of diffraction. Some XRD diffraction patterns of the solid kaolin particles and NR composites were subsequently produced (Figures 3 and 4).

\section{Assessment of the kaolin filler and dispersion of the kaolin particles in the rubbers by electron microscopy}

The kaolin was investigated by a transmission electron microscope (TEM) model 2000FX (JEOL, Japan). A small amount of the dry kaolin powder, approximately 0.1 $\mathrm{g}$ in weight, was placed in a glass tube and mixed with $3 \mathrm{ml}$ of a HPLC grade methanol solvent (Fisher Scientific, UK). The glass tube was then placed in an ultrasonic machine for 15 minutes in order to disperse the kaolin particles in the solvent. After this time elapsed, an electron transparent standard holey carbon film 10-20 nm thick was placed on a copper mesh grid 25 microns thick for TEM samples and inserted in the tube to collect the kaolin nanoparticles. The grid was recovered and placed on a clean tissue paper to remove excess solvent and left in a clean cabinet at room temperature $\left(20^{\circ} \mathrm{C}\right)$ for 24 hours to allow the solvent to fully evaporate before placing it in the TEM. Some micrographs were then prepared for final analysis (Figure 5). 
To select a suitable mixing time for incorporating the kaolin in the rubbers, the mixing time was increased to 24 min to disperse the kaolin particles fully in the rubber. Twenty-four hours after the mixing ended, the rubbers were examined in a scanning electron microscope (SEM) to assess the filler dispersion. Dispersion of the kaolin particles in the rubber was assessed by a Cambridge Instruments Stereoscan 360 Tungsten filament scanning electron microscope. Small pieces of the uncured rubber were placed in liquid nitrogen for 3 min and then fractured to create two fresh surfaces. The samples, $9 \mathrm{~mm}^{2}$ in area and $7 \mathrm{~mm}$ thick, were coated with gold and then examined and photographed in the SEM. The degree of dispersion of the kaolin particles in the rubber was then studied from SEM micrographs. After the micrographs were examined, a total mixing time of 13 min was found to be sufficient to fully disperse the kaolin particles in the rubbers (Figure 6). This mixing time was then used to make rubber compounds for this study.

\section{Results and discussion}

\section{New optimum sulfur cure systems for the rubbers}

Figure 7 shows $\Delta$ torque as a function of TBBS loading for the NR rubbers with 1 and $4 \mathrm{phr}$ sulfur. For the rubber with $1 \mathrm{phr}$ sulfur, $\Delta$ torque increased from 5 to $23 \mathrm{dNm}$ as the loading of TBBS was raised to $1.5 \mathrm{phr}$, and it continued rising at a much slower rate to about $32 \mathrm{dNm}$ when the loading of TBBS reached $3.5 \mathrm{phr}$. The addition of 1.5 phr TBBS was sufficient to react the sulfur with the rubber to form crosslinks. For the rubber with 4 phr sulfur, $\Delta$ torque increased from 24 to $41 \mathrm{dNm}$ as the loading of TBBS was increased from 0.5 to $3.5 \mathrm{phr}$. Subsequently, $\Delta$ torque rose to $43 \mathrm{dNm}$ when an additional $1 \mathrm{phr}$ TBBS was incorporated in the rubber. Clearly, $3.5 \mathrm{phr}$ TBBS was sufficient to react the sulfur with the rubber. 
To enhance the efficiency of cure in the NR with sulfur and TBBS, $\mathrm{ZnO}$ was added (Figure 8). The addition of $0.2 \mathrm{phr} \mathrm{ZnO}$ to the rubber with $1 \mathrm{phr}$ sulfur and 1.5 phr TBBS was enough to improve the efficiency of TBBS as indicated by increase in $\Delta$ torque from 21 to $26 \mathrm{dNm}$. However, when the loading of $\mathrm{ZnO}$ was raised to $0.5 \mathrm{phr}$, $\Delta$ torque rose at a much slower rate to about $33 \mathrm{dNm}$. Similarly, $\Delta$ torque for the rubber with $4 \mathrm{phr}$ sulfur and $3.5 \mathrm{phr}$ TBBS reached optimum value at $0.2 \mathrm{phr} \mathrm{ZnO}$ and thereafter the rise was marginal. Note that a small amount of $\mathrm{ZnO}$, i.e. as low as $0.2 \mathrm{phr}$, when added as primary activator, improved the performance of TBBS to such a degree during curing as shown by increase in $\Delta$ torque.

Stearic acid is a fatty acid that is added as co-activator with $\mathrm{ZnO}$ in sulfur vulcanization. It also acts as plasticiser and internal lubricant between polymer chains, and aids dispersion of solid ingredients in the rubber. Zinc stearate is formed when stearic acid reacts with $\mathrm{ZnO}$ and is an essential cure activator. ${ }^{46}$ The loading of stearic acid in the NR with $1 \mathrm{phr}$ sulfur, $1.5 \mathrm{phr}$ TBBS and $0.2 \mathrm{phr} \mathrm{ZnO}$ was raised from 0 to $2.5 \mathrm{phr}$ to increase the dispersion and solubility of $\mathrm{ZnO}$ and enhance efficiency of the curing reaction in the rubber. Figure 9 shows $\Delta$ torque versus stearic acid loading. The inclusion of stearic acid in the cure system had no benefit for $\Delta$ torque at all, which stayed constant at about $27 \mathrm{dNm}$. It is abundantly clear that $\mathrm{ZnO}$ is a very effective primary activator in improving the performance of TBBS in the absence of secondary activators such as stearic acid.

Figure 10 shows $\Delta$ torque as a function of TBBS loading for the BR rubbers with 0.5 and 1 phr sulfur. For the rubber with $0.5 \mathrm{phr}$ sulfur, $\Delta$ torque increased from 25 to $45 \mathrm{dNm}$ as the loading of TBBS was raised to $1.75 \mathrm{phr}$, and then it stopped rising once the loading of TBBS reached 3 phr. The addition of $1.75 \mathrm{phr}$ TBBS was sufficient to react the sulfur with the rubber to form crosslinks. For the rubber with 1 
phr sulfur, $\Delta$ torque increased from 39 to $61 \mathrm{dNm}$ as the loading of TBBS was raised from 0.5 to 3 phr. Subsequently, $\Delta$ torque remained essentially unchanged when an additional $0.8 \mathrm{phr}$ TBBS was incorporated in the rubber. Clearly, 3 phr TBBS was sufficient to react the sulfur with the rubber.

Zinc oxide was then added to enhance the efficiency of cure in the BR with sulfur and TBBS. For the rubber with $0.5 \mathrm{phr}$ sulfur and $1.75 \mathrm{phr}$ TBBS, the addition of 0.2 phr $\mathrm{ZnO}$ was enough to make TBBS more effective as indicated by increase in $\Delta$ torque from 62 to $71 \mathrm{dNm}$. But when the loading of $\mathrm{ZnO}$ was raised to $0.35 \mathrm{phr}$, $\Delta$ torque showed no increase and remained at about $72 \mathrm{dNm}$ (Figure 11). $\Delta$ Torque for the rubber with $1 \mathrm{phr}$ sulfur and 3 phr TBBS reached optimum value, i.e. $92 \mathrm{dNm}$, at $0.2 \mathrm{phr} \mathrm{ZnO}$, and afterwards it rose marginally to about $94 \mathrm{dNm}$ when an extra $0.25 \mathrm{phr} \mathrm{ZnO}$ was added. Notably, when $0.5 \mathrm{phr}$ stearic acid was added to the BR with $0.5 \mathrm{phr}$ sulfur, $1.75 \mathrm{phr}$ TBBS and $0.2 \mathrm{phr} \mathrm{ZnO}, \Delta$ torque first decreased sharply from 71 to $50 \mathrm{dNm}$ and then remained almost steady until the loading of stearic acid reached 2.5 phr. Evidently, small amounts of stearic acid, i.e. up to $0.5 \mathrm{phr}$, were detrimental to the crosslink density of the rubber as indicated by drop in $\Delta$ torque (Figure 9).

Figure 12 demonstrates $\Delta$ torque versus TBBS loading for the EPDM with $1 \mathrm{phr}$ sulfur. $\Delta$ Torque increased steeply from 26 to $42 \mathrm{dNm}$ as the loading of TBBS was boosted from 0.25 to $1 \mathrm{phr}$. Subsequently, there was no improvement in $\Delta$ torque once the amount of TBBS reached $3.8 \mathrm{phr}$. Apparently, $1 \mathrm{phr}$ TBBS was enough to react the sulfur with the rubber. Zinc oxide was later added to improve the efficiency of TBBS. $\Delta$ Torque rose noticeably from $41 \mathrm{dNm}$ at $0 \mathrm{phr} \mathrm{ZnO}$ to $56 \mathrm{dNm}$ at $0.075 \mathrm{phr}$ $\mathrm{ZnO}$ and the rate of increase slowed down significantly thereafter. $\Delta$ torque then reached to about $67 \mathrm{dNm}$ when the loading of $\mathrm{ZnO}$ was raised by an additional 0.325 
phr (Figure 13). It is remarkable that a small amount of $\mathrm{ZnO}$, i.e. as low as $0.075 \mathrm{phr}$, had such a major influence on the performance of TBBS in the cure system as indicated by a significant rise in $\Delta$ torque. When $0.5 \mathrm{phr}$ stearic acid was mixed with the EPDM with $1 \mathrm{phr}$ sulfur, $1 \mathrm{phr}$ TBBS and $0.075 \mathrm{phr} \mathrm{ZnO}, \Delta$ torque decreased from 56 to $47 \mathrm{dNm}$ and subsequently continued decreasing slowly to about $42 \mathrm{dNm}$ when the amount of stearic acid was raised to $2.5 \mathrm{phr}$ (Figure 9). The crosslink density as shown by $\Delta$ torque did not benefit from the addition of stearic acid to the rubber and consequently it can be eliminated from the cure system completely. In the absence of stearic acid, no zinc stearate was formed in the rubber. Hence, zinc stearate is not an essential ingredient in the curing of rubber as has been claimed. ${ }^{46}$

After these measurements were completed, three cure systems were selected for further work. For NR, the cure system consisted of $4 \mathrm{phr}$ sulfur, $3.5 \mathrm{phr}$ TBBS, and $0.2 \mathrm{phr} \mathrm{ZnO}$; for BR, 0.5 phr sulfur, $1.75 \mathrm{phr}$ TBBS and $0.2 \mathrm{phr} \mathrm{ZnO}$; for EPDM, $1 \mathrm{phr}$ sulfur, $1 \mathrm{phr}$ TBBS and $0.075 \mathrm{phr} \mathrm{ZnO}$. To protect the rubbers against environmental ageing, $1 \mathrm{phr}$ antidegradant (6PPD) was also added. Note that there were only three chemicals in the cure systems, i.e. sulfur, TBBS and $\mathrm{ZnO}$, which added up to $7.7 \mathrm{phr}$ in the NR compounds, $2.45 \mathrm{phr}$ in the BR compounds and 2.075 phr in the EPDM compound. This is a significant reduction both in the number and amount of the chemicals in the cure system. In addition to the chemical curatives, the NR compounds had 60 and $140 \mathrm{phr}$ kaolin and the BR and EPDM compounds 60 phr kaolin (compounds 1-7, Table 1). These compounds were mixed as described already and their viscosity and cure properties measured. They were then cured at $160^{\circ} \mathrm{C}$ and their hardness, tensile properties and tear energy determined.

Effect of kaolin on the viscosity and cure properties of the rubber compounds 
The inclusion of kaolin affected the viscosity and cure properties of the rubbers not in the same way. The viscosity of NR increased from 44 to 85 MU when 140 phr kaolin was added (Figure 14). A similar trend was also observed for BR and EPDM where the viscosity rose from 42 to $66 \mathrm{MU}$ and from 70 to $89 \mathrm{MU}$, respectively after 60 phr kaolin was mixed (Table 1). This was expected, since the inclusion of solid particles in raw rubber raises the rubber viscosity. ${ }^{47}$

The $t_{\mathrm{s} 2}$ and $\mathrm{t}_{95}$ of NR shortened from 4.7 to $2.1 \mathrm{~min}$ and 8.3 to $3.1 \mathrm{~min}$, respectively with 140 phr kaolin (Figure 15). The rate of cure as indicated by CRI benefitted greatly from kaolin and increased from 27.8 at 0 phr kaolin to $100 \mathrm{~min}^{-1}$ at 140 phr kaolin loading (Figure 16). Probably, this was the highest cure rate ever reported for a sulfur-cured NR-based compound. As mentioned earlier, $\Delta$ torque is an indication of crosslink density changes in the rubber. $\Delta$ torque for NR increased from 43 to $69 \mathrm{dNm}$ as the loading of kaolin was raised from $0 \mathrm{phr}$ to $140 \mathrm{phr}$, which indicated a large rise in the crosslink density of the rubber (Figure 17).

For $\mathrm{BR}$, the addition of kaolin shortened the $\mathrm{t}_{\mathrm{s} 2}$ and $\mathrm{t}_{95}$ from 11.3 to $3.5 \mathrm{~min}$ and 47.5 to $12.5 \mathrm{~min}$, respectively. The rate of cure also improved from 2.8 to $11.1 \mathrm{~min}^{-1}$. Though, kaolin had a detrimental effect on the crosslink density of the rubber because $\Delta$ torque decreased from 72 to $56 \mathrm{dNm}$ (Table 1).

For EPDM, the $\mathrm{t}_{\mathrm{s} 2}$ decreased from 6.2 to $2.6 \mathrm{~min}$ but surprisingly, the t95 $_{95}$ increased from 21.5 to 40 min when 60 phr kaolin was added. Compound 7 had a marching cure and the torque kept increasing as a function of time. To calculate an optimum cure time for this compound, an arbitrary maximum torque value was considered. Hence, there was some uncertainty regarding the exact optimum cure time of this compound. But, it was evident that kaolin retarded the cure, causing it to 
march indefinitely. It is worth mentioning that the remaining compounds in Table 1 had equilibrium cure (Figure 1). The rate of cure declined as shown by a large fall in CRI from 6.5 to $2.7 \mathrm{~min}^{-1}$. The rubber lost some crosslinks as demonstrated by reduction in $\Delta$ torque from 55 to $44.5 \mathrm{dNm}$ (Table 1). This revealed the damaging effect of kaolin on the crosslink density of both BR and EPDM.

Effect of kaolin on the hardness and mechanical properties of the rubber composites

Table 2 summarizes the hardness and mechanical properties of the rubber composites. These properties benefitted to a great extent from the addition and progressive increases in the loading of kaolin. For NR, the hardness increased by $64 \%$ when 60 phr kaolin was added and the trend continued rising by another $28 \%$ when the loading of kaolin reached 140 phr. Similarly, the Young's modulus rose by $170 \%$ with 60 phr kaolin and then by an extra 148\% when the full amount of kaolin, i.e. 140 phr, was reached. This was expected, since when soft rubber is replaced with solid filler, the rubber becomes harder, causing the Young's modulus to increase. The tensile strength and tear energy were unchanged and the elongation at break and stored energy density at break deteriorated by a total of $65 \%$ and $34 \%$, respectively when 140 phr kaolin was mixed with the rubber. Notably, the compression set of the rubber was adversely affected by the addition of kaolin. For the unfilled rubber, the set was $41 \%$, and it then rose to $64 \%$ and $71 \%$, when 60 and 140 phr kaolin was added, respectively.

Kaolin was very beneficial to the properties of BR and EPDM. For BR, the hardness increased by $23 \%$ and for EPDM, by $34 \%$, respectively when 60 phr kaolin was incorporated in the rubbers. For BR, the tensile strength, elongation at break and Young's modulus rose by $759 \%, 256 \%$ and $114 \%$, respectively. The 
compression set of the unfilled rubber was $9.4 \%$, and subsequently rose to $26 \%$ when 60 phr kaolin was mixed with the rubber.

The effect of kaolin on the properties of EPDM was even more impressive. For this rubber, the tensile strength, elongation at break and Young's modulus improved by $964 \%, 332 \%$ and $71 \%$, respectively. The properties related to fracture were also enhanced very substantially. For BR, the stored energy density at break and tear energy were increased by $2442 \%$ and $536 \%$, respectively and for EPDM, by $3133 \%$ and $1479 \%$, respectively. The compression set of the unfilled rubber was $39 \%$, and afterward increased to $48 \%$ with $60 \mathrm{phr}$ kaolin. Hence kaolin was detrimental to the compression set resistance of these rubbers.

Evidently, kaolin is extending or non-reinforcing filler for the strain-induced crystallizing NR, and highly reinforcing for the non-crystallizing BR and EPDM. Since kaolin has a platelet structure (Figure 5), it may be assumed that the mechanism by which rubber is reinforced may be different to that by spherical particles such as CB and silica. The results suggest that strain-induced crystallizing NR benefits less from kaolin than the non-crystallizing BR and EPDM do. In a study ${ }^{48}$, some rubber composites were obtained by mixing NR, BR, and EPDM with up to 60 phr kaolin. The cure system consisted of $3 \mathrm{phr}$ primary and secondary accelerators and $4 \mathrm{phr}$ primary and secondary activators, adding up to $7 \mathrm{phr}$, as well as $2.5 \mathrm{phr}$ sulfur. The kaolin-filled rubber composites had outstanding mechanical and thermal properties. For the NR composite, the highest hardness (38 Shore A), tensile strength (10.10 $\mathrm{MPa}$ ) and elongation at break (296\%) were recorded at $40 \mathrm{phr}$ loading of kaolin. For the BR composite, the highest hardness (58 Shore A), tensile strength (7.75 MPa) and elongation at break (53\%) were measured at 50 phr loading of kaolin. Finally, for the EPDM composite, the highest hardness (58 Shore A), tensile strength $(9.26 \mathrm{MPa})$ 
and elongation at break (208\%) were determined at 50 phr kaolin, respectively. Our results compared well with the reported ones above. For instance, the filled EPDM composite had a hardness of 55 Shore A, tensile strength of $14.9 \mathrm{MPa}$ and an elongation at break of $1512 \%$, significantly better than those reported for the EPDM above, in spite of the cure system having one accelerator and one activator, adding up to 2.075 phr (Table 1). All the indications are that kaolin reinforces rubber effectively, and reduction in the use of the chemical curatives in the vulcanization process does not affect the mechanical properties of the rubbers adversely.

There are various factors which affect reinforcement of rubbers by solid fillers. They are filler-rubber interaction ${ }^{49,50}$, filler-filler interaction ${ }^{51}$, and formation of crosslinks in rubber. ${ }^{4,40}$ Increasing mixing time is an effective way to disperse solid fillers in rubber compounds. ${ }^{52}$ As Figure 6 shows, the kaolin particles dispersed well in the rubber matrix. The reinforcing effect of kaolin on the mechanical properties was optimized through good dispersion ${ }^{53}$ and consequently the filler-filler interaction was minimal. The rubber breaks down during mixing, which causes reduction in molecular weight and viscosity. This is often compensated by the reinforcing effect of the filler. The reduction in molecular weight is attributed to the mechanical rupture of the primary carbon-carbon bonds that are present along the backbone of the rubber chains. ${ }^{54}$ For example, for unfilled NR, a mixing time of 11 min reduced the molecular weight by roughly $25 \%{ }^{55}$ and its viscosity by $13 \% .{ }^{56}$ As the results in Table 2 show, in spite of a long mixing, i.e. $13 \mathrm{~min}$, the mechanical properties of the BR and EPDM composites improved significantly when kaolin was added. This showed the reinforcing capabilities of kaolin.

Solid fillers reinforce rubber properties because of their large surface area. There were at least two contributions made to the rubber-kaolin interaction. Kaolin had a 
surface area of $25 \mathrm{~m}^{2} / \mathrm{g}$ and this provided area for bound rubber to form. The formation of bound rubber increases with factors such as temperature, time, surface activity and surface area of the filler. ${ }^{5} \mathrm{~A}$ mixing temperature of $58-62^{\circ} \mathrm{C}$ and a mixing time of 13 min provided a favourable condition for bound rubber to form in the composites. In addition, the silanization of the kaolin surface with MPTS, helped to improve the filler dispersion and increased the available surface area for rubber to interact with the filler to form bound rubber. Viscosity increases as a function of bound rubber, and bound rubber improves as a function of filler surface area and filler loading. ${ }^{57}$ The results in Table 1show large increases in the viscosity for the kaolin-filled rubbers, signifying bound rubber formation in the composites. Effect of bound rubber on the filler-rubber interaction has been studied extensively and all the results suggest major enhancement of this property when bound rubber forms. ${ }^{5}$

In a study, modified kaolin was introduced into NR and cured at $140^{\circ} \mathrm{C}$ for $10 \mathrm{~min}$ to produce some composites. ${ }^{35}$ The interspacing between the kaolin layers measured by XRD was from 7 to $14 \mathrm{~A}^{\circ}$. The presence of the modified kaolin resulted in increase in the torque value caused by the formation of a higher number of crosslinks, which was attributed to the confinement of the rubber chains within the silicate galleries and hence to better interaction between the filler and the rubber. The XRD indicated a gallery spacing of about $7 \mathrm{~A}^{\circ}$ for the kaolin used in this study. Since the size of a carbon atom along the backbone of hydrocarbon rubber is about $3 A^{0}{ }^{58}$ it is likely that some segments of the rubber chains entered into the kaolin galleries during mixing, causing strong interaction between the two. This in turn, could have enhanced the kaolin-rubber interaction and improved the properties of the BR and EPDM composites (Table 2). It seems that confinement of the rubber chains within a layered structure is a major factor in the ability of mineral fillers such 
as kaolin to reinforce the rubber properties. Apparently, this was not so for the NR composite.

The NR viscosity increased by approximately $64 \%$ when the loading of kaolin was raised from 60 to 140 phr (Table 1). When the viscosity rose, higher shear forces were produced in the rubber, resulting in a more efficient break down of the filler aggregates, better dispersion of the filler particles and more surface area for the rubber chains to interact with (Figure 6). Consequently, more bound rubber was formed in the kaolin-filled composites. Furthermore for NR, the peaks on the XRD patterns of the kaolin-filled composites were the same as the ones appearing on the XRD pattern of the kaolin particles but getting larger as more kaolin was added (cf. Figure 3 with Figure 4). It was concluded that there was no evidence of crystallization in the rubber. Small amounts of suitable impurities accelerate the crystallization process markedly in NR in the absence of strain, presumably by promoting crystal nucleation. ${ }^{59}$ Clearly, this was not the case with kaolin.

As mentioned earlier, $\Delta$ torque is an indication of crosslink density changes in rubber. The $\Delta$ torque of the NR composites increased from 43 to $69 \mathrm{dNm}$ when the loading of kaolin was raised from 0 to $140 \mathrm{phr}$, respectively (Table 1). This indicated a significant rise in the crosslink density of the composite. For the BR and EPDM composites, $\Delta$ torque decreased by approximately $22 \%$ and $19 \%$, respectively when 60 phr kaolin was added (Table 1).

The compression set of the composites increased when kaolin was incorporated in the rubber (Table 2). In the swelling tests, the unfilled NR composite solvent intake was $489 \%$, and decreased to $347 \%$ and $335 \%$ for the composites with 60 and 140 phr kaolin, respectively. The decrease in solvent intake correlated well with the increase in $\Delta$ torque (Table 1), since higher crosslink density inhibits chain mobility 
and reduces swelling. ${ }^{46}$ But the compression set increased by $73 \%$ when the kaolin loading was raised to $140 \mathrm{phr}$. This trend did not match that of the $\Delta$ torque (Table 2) because higher crosslink density should have reduced the set. The reason for this discrepancy is not immediately clear but it is likely that the NR composites had more physical links and less chemical crosslinks, which affected both the extent of swelling and $\Delta$ torque.

For the unfilled and filled BR and unfilled and filled EPDM composites, the solvent intake was $360 \%$ and $428 \%$, and $263 \%$ and $323 \%$, respectively. The higher solvent intake indicated lesser crosslink density or lower $\Delta$ torque than the unfilled counterparts. This meant higher compression set for the filled composites. As shown in Table 2, the filled BR and EPDM composites did have lower $\Delta$ torques, which implied lesser crosslink density and higher compression set. It appeared that kaolin was detrimental to the crosslink density of these composites. It is expected that swelling of the BR and EPDM composites was affected mostly by the chemical crosslinks and less by the physical ones. Therefore, chemical and physical crosslinks influenced the $\Delta$ torque and solvent intake in these composites though the exact contribution to the crosslink density remains to be determined.

Glass transition temperature is governed by the extent of chain mobility within the rubber network. When chain mobility is inhibited, e.g. by the presence of chemical and/or physical crosslinks between the rubber chains and strong rubberfiller interaction, $\mathrm{Tg}$ rises. ${ }^{60}$ The $\mathrm{Tg}$ of the unfilled NR composite was $-41^{\circ} \mathrm{C}$ and rose to about -42 and $-43^{\circ} \mathrm{C}$ when the filler loading was $60 \mathrm{phr}$ and $140 \mathrm{phr}$, respectively (Table 2). The Tg for the unfilled and filled BR composites and unfilled and filled EPDM composites were $-100^{\circ} \mathrm{C}$ and $-97^{\circ} \mathrm{C}$, and $-42^{\circ} \mathrm{C}$ and $-40^{\circ} \mathrm{C}$, respectively. The kaolin filler raised the $\mathrm{Tg}$ of the composites by up to three degrees centigrade. 


\section{Conclusions}

From this study, the following main conclusions can be drawn.

1. A new method measured the exact optimum amount of TBBS accelerator and $\mathrm{ZnO}$ activator at a given loading of sulfur in the composites of NR, BR and EPDM and eliminated stearic acid from the cure system entirely. The requirement for $\mathrm{ZnO}$ was $0.075-0.2 \mathrm{phr}$. interestingly, in spite of using less chemical curatives in sulfur vulcanization, the rubber composites were fully cured with outstanding properties.

2. Kaolin was extending or non-reinforcing filler for the strain-induced crystallizing NR and highly reinforcing for the non-crystallizing BR and EPDM.

It is predictable that reduction in the use of $\mathrm{ZnO}$ and stearic acid will improve health and safety at work-place, reduce cost, and minimise damage to the environment. The use of MPTS pre-tread kaolin in conjunction with the new method for measuring the exact amount of the curatives in sulfur vulcanization provides an effective means for designing green composites for industrial applications. The indications are that MPTS pre-treated kaolin is an ideal replacement for carbon black and silica/silane systems in rubber reinforcement, at least for non-crystallizing BR and EPDM rubbers.

\section{Acknowledgment}

We thank Mr Keith Grandstaff of Imerys Ceramics for providing the kaolin powder. We also than Dr Zhaoxia Zhou of LMCC for performing the TEM work.

\section{Declaration of conflicting interests}

The authors declared no potential conflict of interest with respect to the research, authorship, and/or publication of this article.

\section{Funding}


The authors received no financial support for the research, authorship, and /or publication of this article. 


\section{References}

1. Dunnom DD. Use of reinforcing silicas. Rubber Age 1968; 100: 49-57.

2. Dannenberg EM. Carbon black dispersion and reinforcement. Rubber ChemTechnol 1982; 25: 843-857.

3. Bristow GM and Tiller RF. Correlation of structure and properties of natural rubber vulcanizates. Kautsch Gummi Kunstst 1970; 23: 55-9.

4. Nasir M and Teh GK. The effects of various types of crosslinks on the physical properties of natural rubber. Eur Polym J 1988; 24: 733-736.

5. Wolff S, Wang MJ and Tan EH. Filler-elastomer interactions. Part VII. Study on bound rubber. Rubber Chem Technol 1993; 66: 163-177.

6. Dannenberg EM. The effects of surface chemical interactions on the properties of filler-reinforced rubbers. Rubber Chem Technol 1975; 48: 410-443.

7. Andrews EH. Reinforcing of rubber by fillers. Rubber Chem Technol 1963; 36: 325-336.

8. Saeed F, Ansarifar A, Ellis RJ, et al. Two advanced styrene-butadiene/ polybutadiene rubber blends filled with a silanized silica nanofiller for potential use in passenger car tire tread compound. J Apply Polym Sci 2012; 123: 1518-1529.

9. Hair ML, Hertl W. Acidity of surface hydroxyl groups. J Phys Chem 1970; 74: 91 94.

10. Hockey JA, Pethica BA. Surface hydration of silicas. Trans Faraday Soc 1961; 57: 2247-2262.

11. Wolff S, Görl U, Wang MJ, Wolff W. Silane modified silicas-silica-based tread compounds. Eur Rubber J 1994; 16: 16-19.

12. Wolff $\mathrm{S}$. Chemical aspects of rubber reinforcement by fillers. Rubber Chem Technol 1996; 69: 325-346. 
13. Li P, Wang L, Song G, et al. Characterization of high-performance exfoliated natural rubber/organoclay nanocomposites. J Appl Poly Sci 2008; 109: 3831-3838.

14. Teh, PL, Mohd Ishak ZA, Hashim AS, et al. Physical properties of natural rubber/organoclay nanocomposites compatibilized with epoxidized natural rubber. J Apply Polym Sci 2006; 100: 1083-1092.

15. Thostenson ET, Li C and Chou TW. Nanocomposites in context. Comp Sci Technol 2005; 65: 491-516.

16. Varghese S, Karger-Kocsis J and Gatos KG. Melt compounded epoxidized natural rubber/layered silicate nanocomposites: structure-properties relationships Polymer 2003; 44: 3977-3983.

17. Rattanasom N, Prasertsri S and Ruangritnumchai T. Comparison of the mechanical properties at similar hardness level of natural rubber filled with various reinforcing-fillers. Polymer Test 2009; 28: 8-12.

18. Jia D, Liu L, Wang $X$ et al. Advances in natural rubber/montmorillonite nanocommposites," in Biodegradabale polymer blends and composites from renewable resources. NJ: John Wiley \& Son, Inc., Hoboken, 2008.

19. Chua TP, Mariatti M, Azizan A et al. Effects of surface-functionalized multi-walled carbon nanotubes on the properties of poly(dimethyl siloxane) nanocomposites. Comp Sci Technol 2010; 70: 671-677.

20. Verdejo R, Saiz-Arroyo C, Carretero-Gonzalez J et al. Physical properties of silicone foams filled with carbon nanotubes and functionalized graphene sheets. Eur Polym J 2008; 44: 2790-2797.

21. Bokobza L. Multiwall carbon nanotube elastomeric composites. A review. Polymer 2007; 48:4907-4920. 
22. Zhan Y, Wu JK, Xia HS, et al. Dispersion and Exfoliation of Graphene in Rubber by an Ultrasonically-Assisted Latex Mixing and In situ Reduction Process. Macromol Mater Eng 2011; 296: 590-602.

23. Lewicki JP, Liggat JJ and Patel M. The thermal degradation behaviour of polydimethylsiloxane/montmorillonite nanocomposites. Polym Degrad Stab 2009; 94: 1548-1557.

24. Sengupta R, Chakraborty S, Bandyopadhyay S, et al. A short review on rubber/clay nanocomposites with emphasis on mechanical properties. Polym Eng Sci 2007; 47: 1956-1974.

25. Kim JK, Pal K and Sridhar V. Recent advances in elastomeric nancomposites: Advanced structured materials, Verlag, Berlin, Heidelberg, 2011, 5.

26. Bokobza L. The Reinforcement of Elastomeric Networks by Fillers. Macromol Mater Eng 2004; 289: 607-621.

27. Das A, Stockelhuber KW, Jurk R et al. Routes to Rubber Nanocomposites. Macromol Symp 2010; 291-292: 95-105.

28. Stephen R and Thomas S. Rubber nanocomposites: Preparation, properties and applications, Wiley, New Jersey 2010 Chapter 1.

29. Paul DR and Robeson LM. Polymer nanotechnology: Nanocomposites. Polymer 2008; 49: 3187-3204.

30. Ahmadi SJ, Huang Y and Li W. Fabrication and physical properties of EPDMorganoclay nanocomposites. Comp Sci Technol 2005; 65: 1069-1076.

31. Labruyère C, Gorrasi G, Monteverde F, et al. Transport properties of organic vapours in silicone/clay nanocomposites. Polymer 2009; 50: 3626-3637.

32. Horsch S, Serhatkulu G, Gulari E et al. Supercritical $\mathrm{CO}_{2}$ dispersion of nanoclays and clay/polymer nanocomposites. Polymer 2006; 47: 7485-7496. 
33. Zoromba Sh M, Belal AAM, Ali AEM et al. Preparation and characterisation of some NR and SBR formulations containing different modified kaolinite. Polym-Plast Technol Eng 2007; 46:529-535.

34. Sukumar R and Menon ARR. Organomodified kaolin as a reinforcing filler for natural rubber. J Apply Polym Sci 2008; 107:3476-3483.

35. Yahaya LE, Adebowale KO and Olu-Owolabi BI. Cure characteristics and rheological properties of modified kaolin-natural rubber composites. Am Chem Sci J 2014; 4: 472-480.

36. Ciullo PA and Hewitt N. The Rubber Formulary, Noyes Publications, New York, 1999, 91.

37. Ostad-Movahed S, Ansar Yasin K, Ansarifar A, et al. Comparing effects of silanized silica nanofiller on the crosslinking and mechanical properties of natural rubber and synthetic polyisoprene. J Appl. Poly. Sci 2008; 109:869-881.

38. Wang MJ. Effect of polymer-filler and filler-filler interaction on dynamic properties of filled vulcanizates. Rubber Chem. Technol 1998; 71: 520-589.

39. http://www.westliberty.edu/health-and-safety/files/2012/08/Stearic-Acid.pdf 40. Brown PS, Porter M and Thomas AG. The dependence of strength properties on crosslinked structure in vulcanized polyisoprenes. Kautsch Gummi Kunstst 1987; 40: 17-19.

41. Hallett $\mathrm{J}$ and Moninot $\mathrm{G}$. The $7^{\text {th }}$ International Conference on Rubber Chemicals, Compounding and Mixing, Vienna Austria December 2010.

42. Ciullo PA and Hewitt N. The rubber formulary. Noyes publications, NY, 1999. P79.

43. Ciullo PA and Hewitt N. The rubber formulary. Noyes publications, NY, 1999. P147. 
44. Ciullo PA and Hewitt N. The rubber formulary. Noyes publications, NY, 1999. P275.

45. Movahed SO, Ansarifar A and Mirzaie F. Effect of various efficient vulcanization cure systems on the compression set of a nitrile rubber filled with different fillers. $J$. Appl. Poly. Sci. 2015; 132:1-10.

46. Datta RN. Rubber curing systems. Rapra review reports, Report 144 2002; 12:1-37.

47. Ansarifar A and Saeed F. Developing ethylene-propylene-dien rubber compounds for industrial applications using a sulfur-bearing silanized silica nanofiller. Polym Compos 2013; 34: 2019-2025.

48. Wu W and Tian L. Formulation and morphology of kaolin-filled rubber composites. Appl Clay Sci 2013; 80-81: 93-97.

49. Leblanc JL. Elastomer-filler interactions and the rheology of filled rubber compounds. J Appl Polym Sci 2000; 78: 1541-1550.

50. Wang MJ, Wolff S and Donnet JB. Filler-elastomer interactions. Part I: Silica surface energies and interactions with model compounds. Rubber Chem Technol $1991 ; 64: 559-576$.

51. Fröhlich J, Niedermeier W and Luginsland HD. The effect of filler-filler and fillerelastomer interaction on rubber reinforcement. Composites Parts A 2005; 36: 449460.

52. Wolff S. Optimization of silane-silica OTR compounds. Pat I: variation of mixing temperature and time during the modification of silica with bis-(3-triethyoxysilylpropyl)-tetrasulfide. Rubber Chem Ttechnol 1982; 55: 967-989. 
53. Cochet $\mathrm{P}$, Barruel $\mathrm{P}$, Barriquand I, et al. Dispersibility measurements of pre. silicas. Influence of dispersion on mechanical properties. Rubber World 1994; 219: 20-24.

54. Ahagon, A. Evaluation of Chain Scission during Mixing of Filled Compounds. Rubber Chem Technol 1996; 69: 742-751.

55. Harmon DJ and Jacobs HL. Degradation of natural rubber during mill mastication. J Appl Polym Sci 1966; 10: 253-257.

56. Fries $\mathrm{H}$ and Pandit RR. Mastication of rubber. Rubber Chem Technol 1982; 55: 309-327.

57. Pliskin I and Tokita N. Bound rubber in elastomers: Analysis of elastomer filler interaction and its effect on viscosity and modulus of composite systems. J. Appl. Poly. Sci 1972; 16: 473-492.

58. http://hyperphysics.phy-astr.gsu.edu/hbase/Particles/atomsiz.html.

59. Gent AN. Crystallisation in natural rubber. II: The influence of impurities. Transactions 1954; 30: 139-143.

60. Cook S, Groves S and Tinker AJ. Investigating crosslinking in blends by differential scanning calorimetry. J Rubb Res 2003; 6: 121-128. 
Table 1. Formulations, Mooney viscosity and cure properties of the rubber compounds

\begin{tabular}{|c|c|c|c|c|c|c|c|}
\hline \multirow{2}{*}{$\begin{array}{c}\text { Formulation } \\
\text { (phr) }\end{array}$} & \multicolumn{7}{|c|}{ Compound no } \\
\hline & 1 & 2 & 3 & 4 & 5 & 6 & 7 \\
\hline $\mathrm{NR}^{*}$ & 100 & 100 & 100 & - & - & - & - \\
\hline $\mathrm{BR}^{*}$ & - & - & - & 100 & 100 & - & - \\
\hline EPDM $^{*}$ & - & - & - & - & - & 100 & 100 \\
\hline Sulfur & 4 & 4 & 4 & 0.5 & 0.5 & 1 & 1 \\
\hline TBBS & 3.5 & 3.5 & 3.5 & 1.75 & 1.75 & 1 & 1 \\
\hline $\mathrm{ZnO}$ & 0.2 & 0.2 & 0.2 & 0.2 & 0.2 & 0.075 & 0.075 \\
\hline Santoflex 13 & 1 & 1 & 1 & 1 & 1 & 1 & 1 \\
\hline Kaolin & 0 & 60 & 140 & 0 & 60 & 0 & 60 \\
\hline \multirow{3}{*}{$\begin{array}{l}\text { Mooney } \\
\text { viscosity }\end{array}$} & \multicolumn{7}{|c|}{$\mathrm{ML}\left(1+4,100^{\circ} \mathrm{C}\right)$} \\
\hline & 44 & 52 & 85 & 42 & 66 & 70 & 89 \\
\hline & \multicolumn{7}{|c|}{ Curemeter data at $160^{\circ} \mathrm{C}$} \\
\hline $\begin{array}{c}\mathrm{M}_{\mathrm{L}} \\
(\mathrm{dNm})\end{array}$ & 12 & 15 & 20 & 15 & 19 & 16 & 19.5 \\
\hline $\begin{array}{c}\mathrm{M}_{\mathrm{H}} \\
(\mathrm{dNm})\end{array}$ & 55 & 79 & 89 & 87 & 75 & 71 & 64 \\
\hline $\begin{array}{c}\Delta \text { Torque } \\
(\mathrm{dNm})\end{array}$ & 43 & 64 & 69 & 72 & 56 & 55 & 44.5 \\
\hline $\begin{array}{c}\mathrm{t}_{\mathrm{s} 2} \\
(\mathrm{~min})\end{array}$ & 4.7 & 3.2 & 2.1 & 11.3 & 3.5 & 6.2 & 2.6 \\
\hline $\begin{array}{c}t_{95} \\
(\min )\end{array}$ & 8.3 & 4.8 & 3.1 & 47.5 & 12.5 & 21.5 & 40 \\
\hline $\operatorname{CRI}\left(\min ^{-1}\right)$ & 27.8 & 62.5 & 100 & 2.8 & 11.1 & 6.5 & 2.7 \\
\hline
\end{tabular}

*The viscosity of the raw NR, BR and EPDM rubbers were 89,46 , and $88 \mathrm{MU}$, respectively. 
Table 2. Hardness and mechanical properties of the rubber vulcanizates

\begin{tabular}{|c|c|c|c|c|c|c|c|}
\hline \multirow[t]{2}{*}{ Properties } & \multicolumn{7}{|c|}{ Compound no } \\
\hline & 1 & 2 & 3 & 4 & 5 & 6 & 7 \\
\hline $\begin{array}{l}\text { Hardness } \\
\text { (Shore A) }\end{array}$ & 33 & 54 & 69 & 44 & 54 & 41 & 55 \\
\hline $\begin{array}{l}\text { Range of } \\
\text { values } \\
\text { (Shore A) }\end{array}$ & $32-35$ & $51-55$ & $68-70$ & $43-44$ & $54-56$ & $41-42$ & $55-56$ \\
\hline $\begin{array}{l}\text { Tensile } \\
\text { strength } \\
\text { (MPa) }\end{array}$ & 22 & 22 & 20 & 1.7 & 14.6 & 1.4 & 14.9 \\
\hline $\begin{array}{l}\text { Range of } \\
\text { values } \\
(\mathrm{MPa})\end{array}$ & $21-22$ & $21-22$ & $18-21$ & $1.5-1.8$ & $\begin{array}{l}14.5- \\
15.5\end{array}$ & 1.3-1.7 & $\begin{array}{l}14.7- \\
17.5\end{array}$ \\
\hline $\begin{array}{c}\text { Elongation at } \\
\text { break }(\%)\end{array}$ & 1667 & 997 & 587 & 250 & 889 & 350 & 1512 \\
\hline $\begin{array}{l}\text { Range of } \\
\text { values (\%) }\end{array}$ & $\begin{array}{l}1645- \\
1669 \\
\end{array}$ & $994-999$ & $577-628$ & $239-283$ & $878-950$ & $333-370$ & $\begin{array}{c}1492- \\
1651 \\
\end{array}$ \\
\hline $\begin{array}{l}\text { Young's } \\
\text { modulus } \\
(\mathrm{MPa})\end{array}$ & 1.0 & 2.7 & 6.7 & 1.4 & 3.0 & 1.4 & 2.4 \\
\hline $\begin{array}{c}\text { Range of } \\
\text { values (MPa) }\end{array}$ & $1.0-1.1$ & $2.3-3.2$ & $5.8-11.6$ & $1.4-1.7$ & $2.8-3.0$ & $1.3-1.4$ & $1.8-2.7$ \\
\hline $\begin{array}{c}\text { Compression } \\
\text { set (\%) }\end{array}$ & 41 & 64 & 71 & 9.4 & 26 & 39 & 48 \\
\hline $\begin{array}{c}\text { Range of } \\
\text { values (\%) }\end{array}$ & $39-42$ & $61-65$ & $71-71$ & $9.4-9.4$ & $26-28$ & $37.5-39$ & $46-50$ \\
\hline $\begin{array}{c}\text { Stored energy } \\
\text { density at } \\
\text { break }\left(\mathrm{mJ} / \mathrm{m}^{3}\right)\end{array}$ & 90 & 90 & 59 & 2.4 & 61 & 3.0 & 97 \\
\hline $\begin{array}{l}\text { Range of } \\
\text { values } \\
\left(\mathrm{mJ} / \mathrm{m}^{3}\right)\end{array}$ & $90-91$ & $86-91$ & $54-65$ & $2.4-3.0$ & $60-70$ & $2.9-3.7$ & $96-121$ \\
\hline $\begin{array}{c}\text { Tear energy } \\
\left(\mathrm{kJ} / \mathrm{m}^{2}\right)\end{array}$ & 13 & 13 & 14 & 1.1 & 7 & 1.9 & 30 \\
\hline $\begin{array}{c}\text { Range of } \\
\text { values } \\
\left(\mathrm{mJ} / \mathrm{m}^{3}\right) \\
\end{array}$ & $11-15$ & $11-20$ & $11-20$ & $0.76-1.7$ & $4.6-11.5$ & $1.3-2.0$ & $26-32$ \\
\hline $\begin{array}{c}\text { Glass } \\
\text { transition } \\
\text { temperature, } \\
\operatorname{Tg}\left({ }^{\circ} \mathrm{C}\right)\end{array}$ & -41 & -43 & -42 & -100 & -97 & -42 & -40 \\
\hline $\begin{array}{c}\text { Degree of } \\
\text { swelling (\%) }\end{array}$ & 489 & 347 & 335 & 360 & 428 & 263 & 323 \\
\hline
\end{tabular}




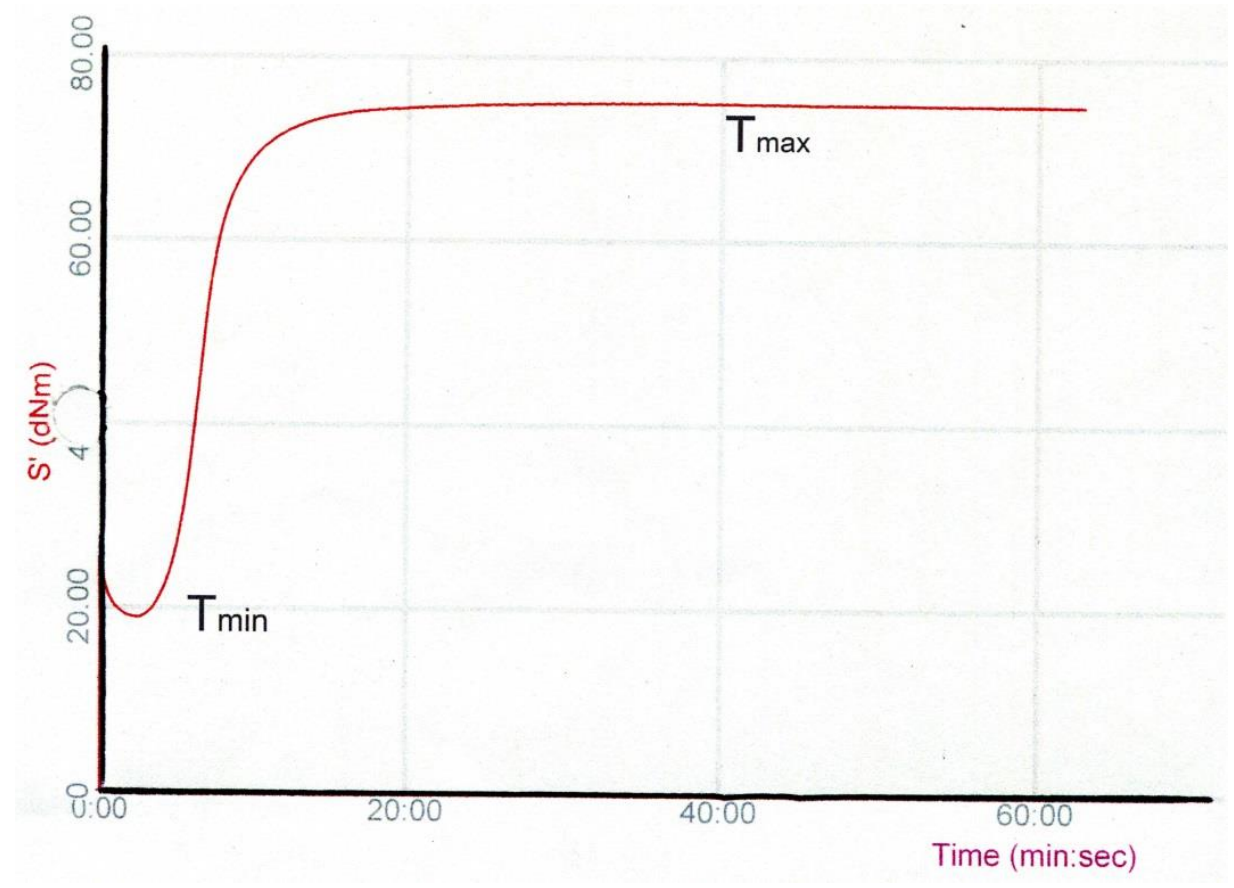

Figure 1. Typical torque vs time cure trace produced by ODR at $160^{\circ} \mathrm{C}$. Data for compound 5 in Table 1. $\Delta \mathrm{T}_{\text {orque }}=\mathrm{T}_{\max }-\mathrm{T}_{\min }$. 


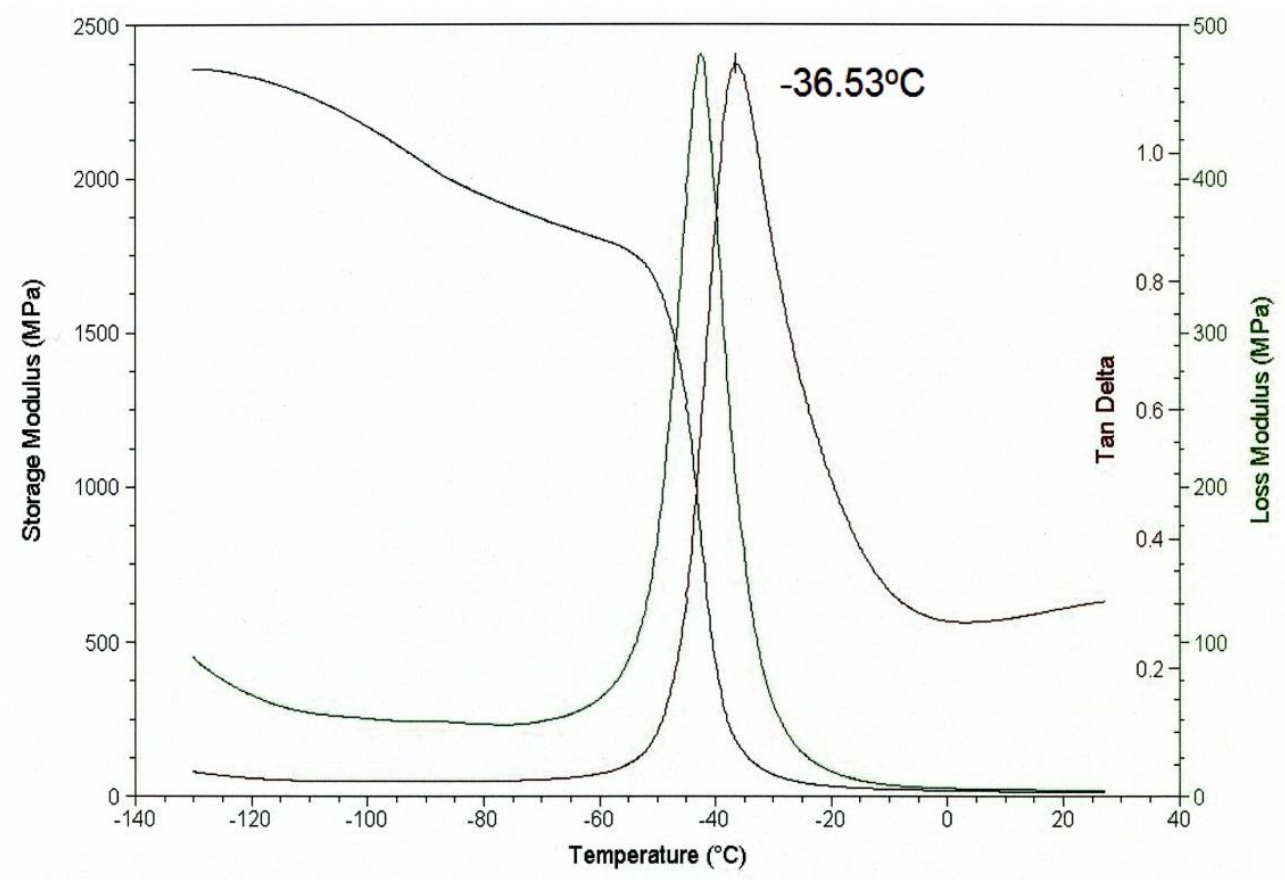

Figure 2. Typical DMA traces for the NR composite with140 phr kaolin. 


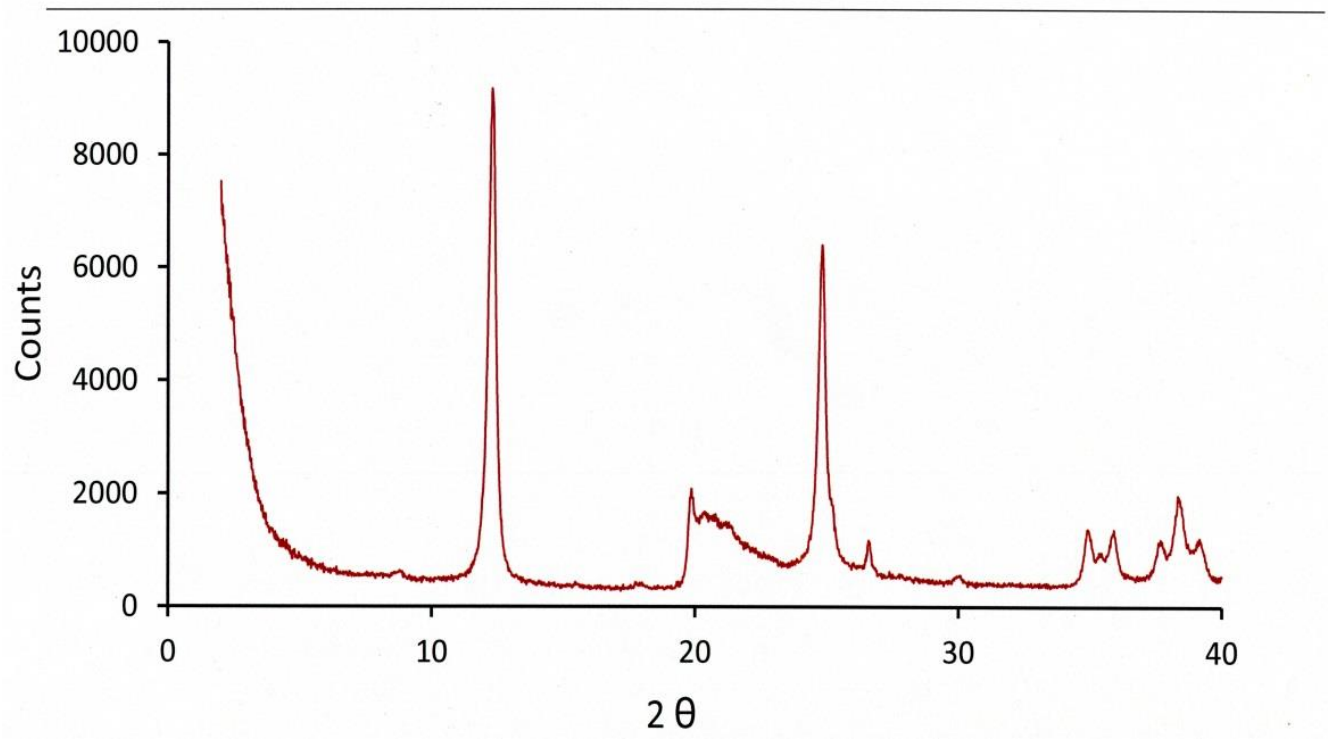

Figure 3. XRD diffraction pattern for the solid kaolin particles. 


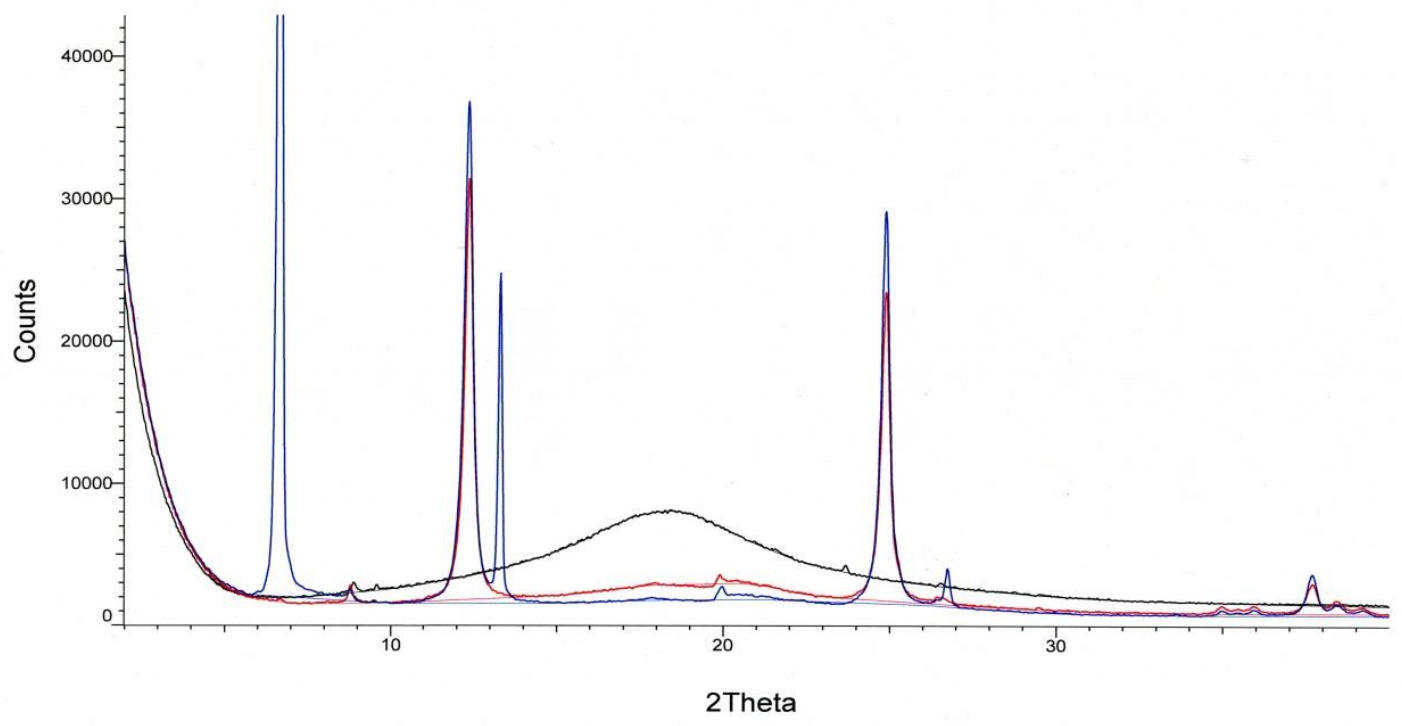

Figure 4. XRD diffraction patterns for the NR composites (compound s 1-3 Table 1). 


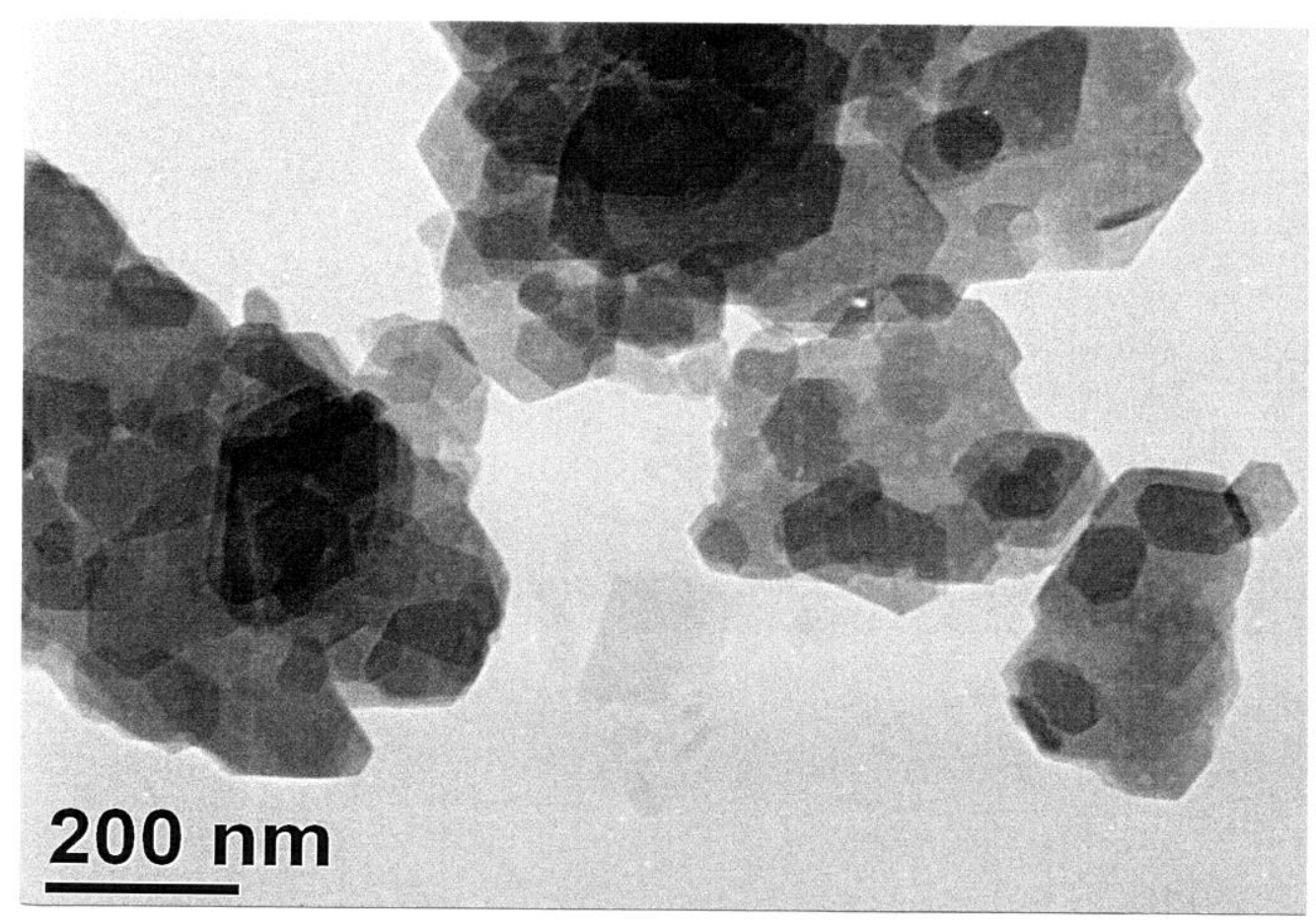

Figure 5. Transmission electron micrograph showing kaolin particles. 


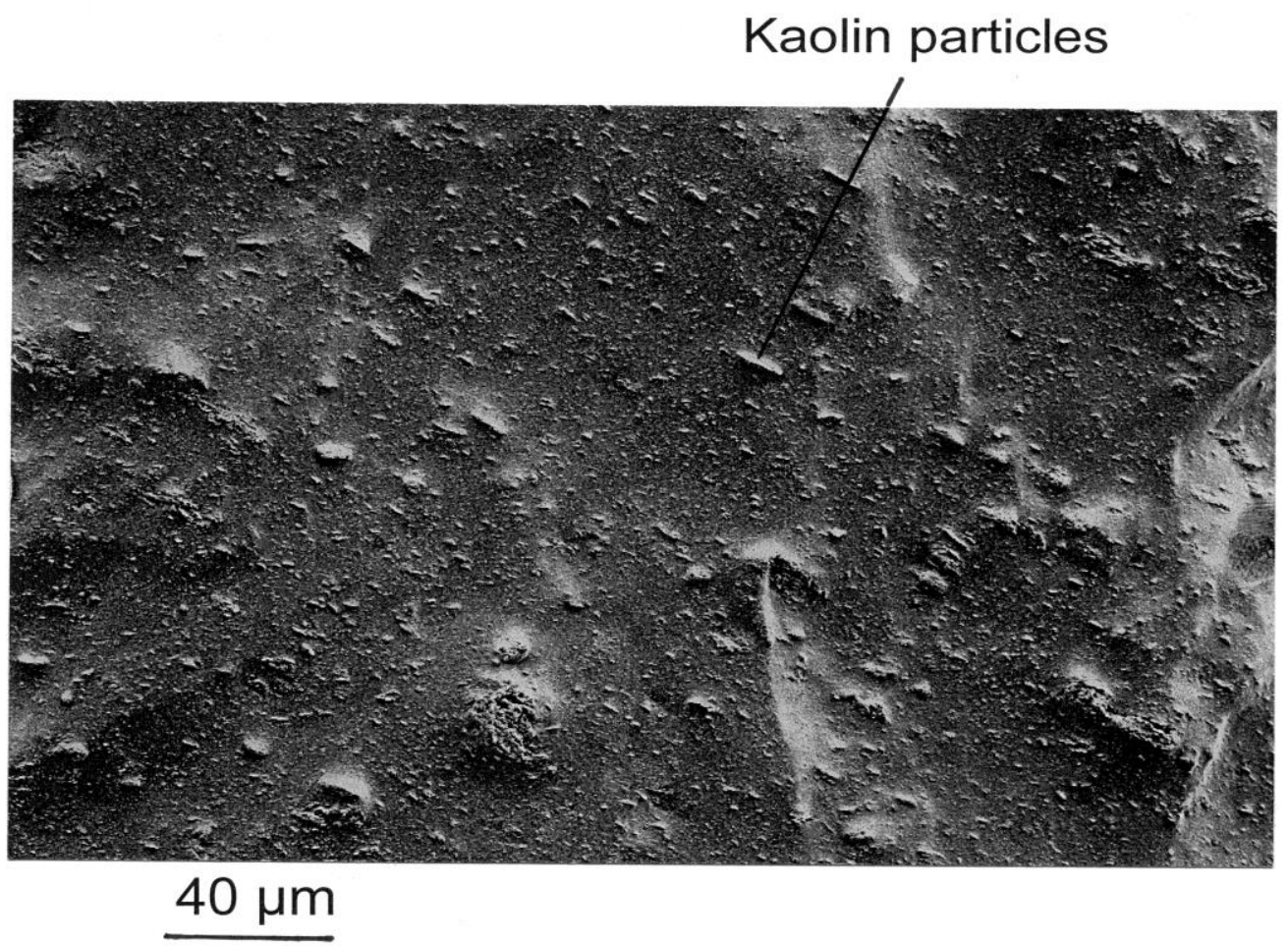

Figure 6. Scanning electron micrograph showing good dispersion of the kaolin particles in rubber matrix. Data for the NR composite with 60 phr kaolin after 13 min mixing time. 


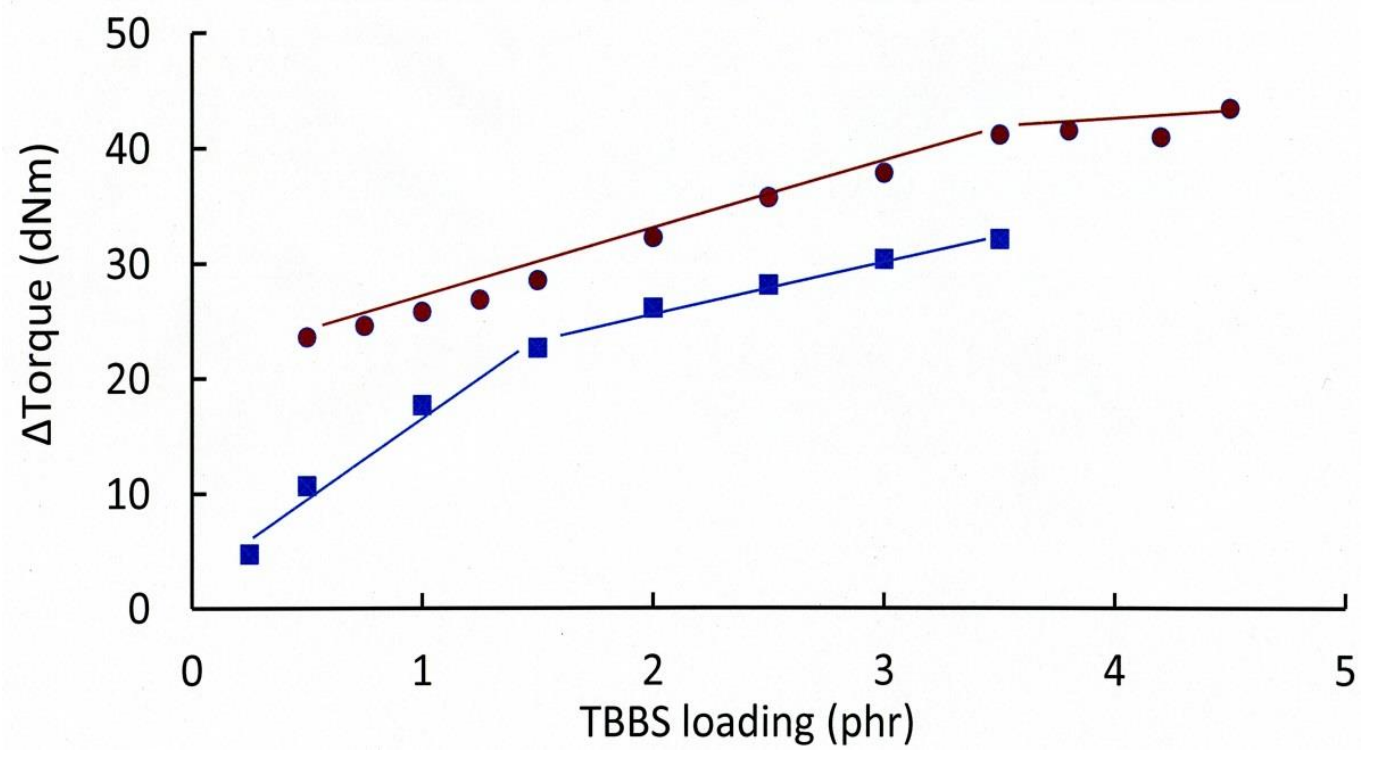

Figure 7. $\Delta$ Torque versus TBBS loading for the NR with $1 \mathrm{phr}$ sulfur ( $\square$ ), NR with 4 phr sulfur $(\bullet)$. 


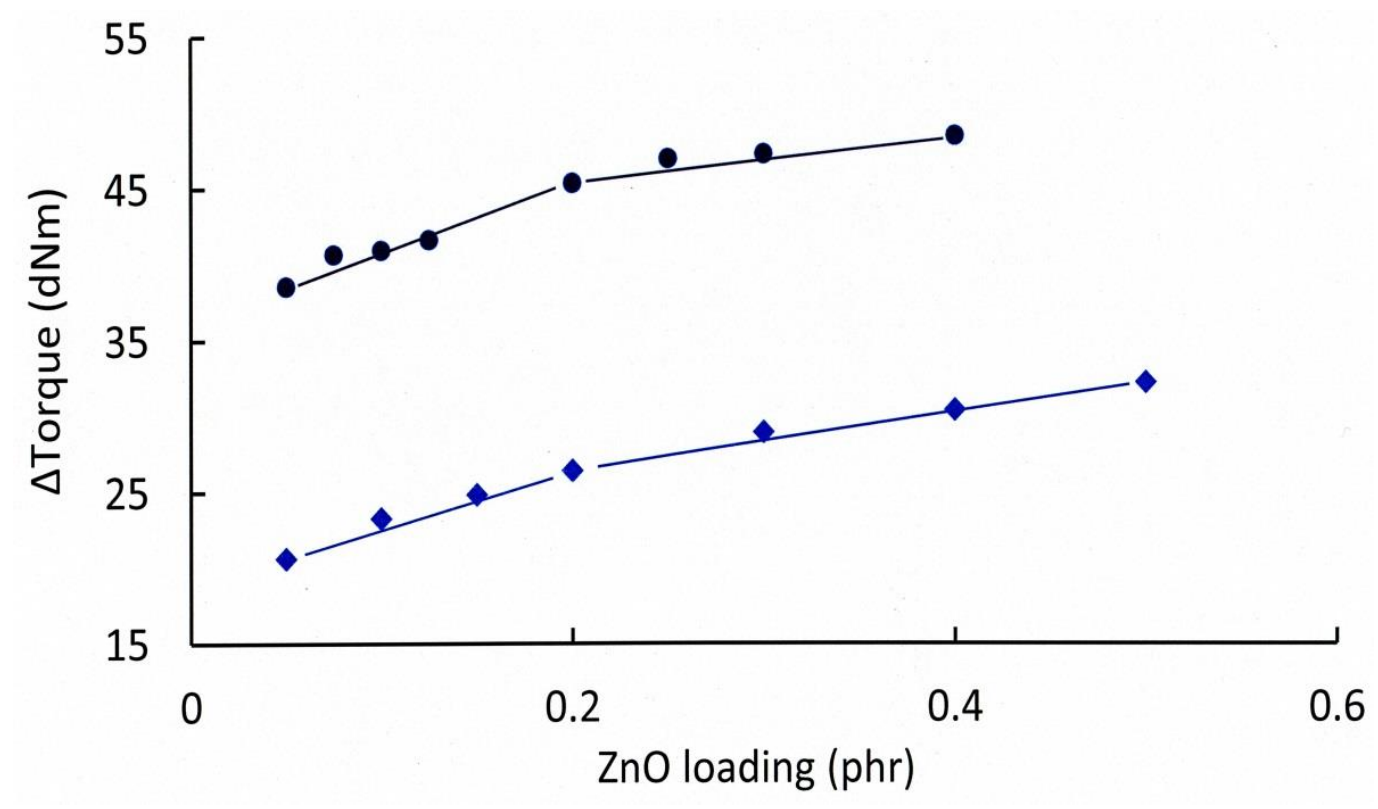

Figure 8. $\Delta$ Torque versus $\mathrm{ZnO}$ loading for the $\mathrm{NR}$ with $1 \mathrm{phr}$ sulfur and $1.5 \mathrm{phr}$ $\operatorname{TBBS}(\diamond)$, NR with 4 phr sulfur and $3.5 \mathrm{phr} \operatorname{TBBS}(\bullet)$. 


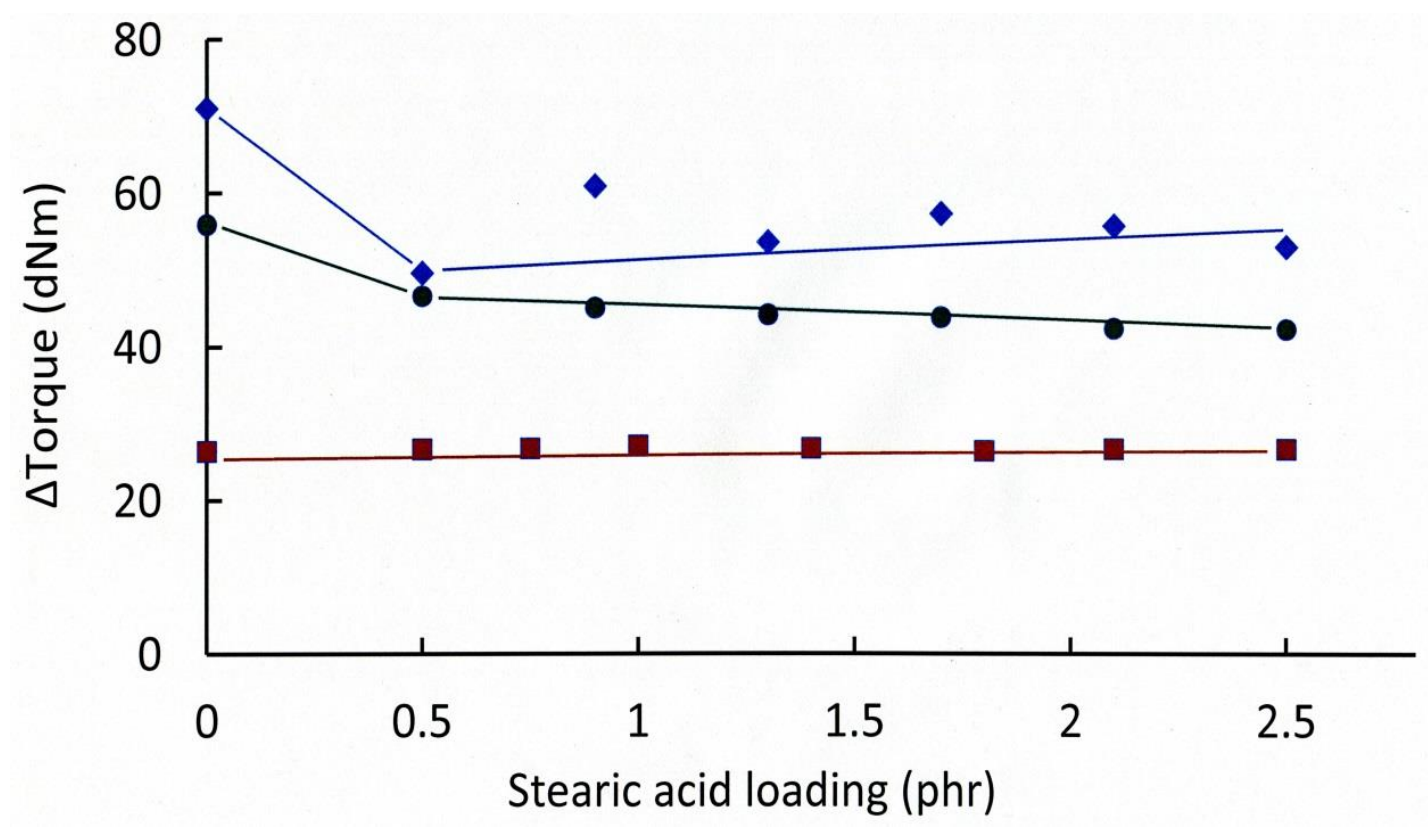

Figure 9. $\Delta$ Torque versus stearic acid loading for the NR with $1 \mathrm{phr}$ sulfur, $1.5 \mathrm{phr}$ TBBS and $0.2 \mathrm{phr} \mathrm{ZnO}(\square)$, BR with $0.5 \mathrm{phr}$ sulfur, $1.75 \mathrm{phr}$ TBBS and $0.2 \mathrm{phr}$ $\mathrm{ZnO}(\diamond)$, EPDM with 1 phr sulfur, 1 phr TBBS and $0.075 \mathrm{phr} \mathrm{ZnO}(\bullet)$. 


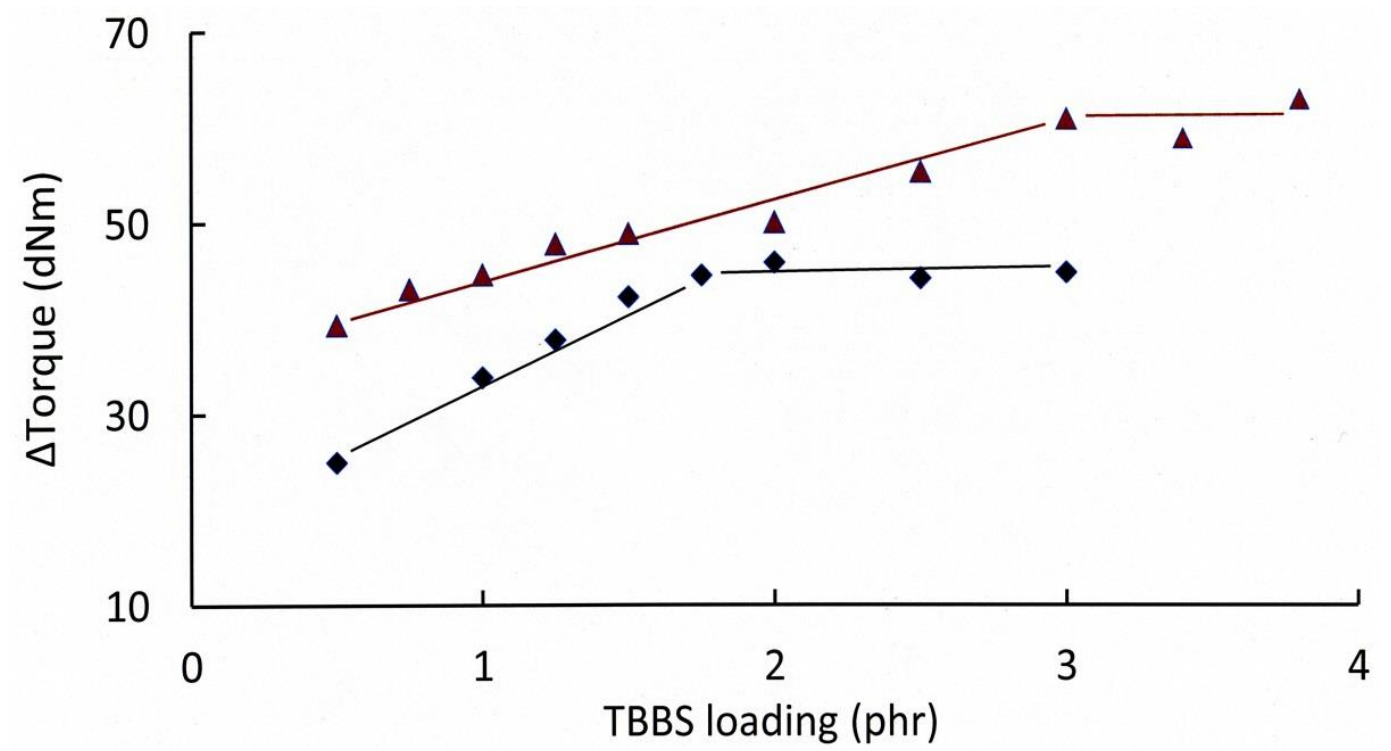

Figure 10. $\Delta$ Torque versus TBBS for the BR with $0.5 \mathrm{phr}$ sulfur $(\checkmark)$, and BR with 1 phr sulfur $(\boldsymbol{\Delta})$. 


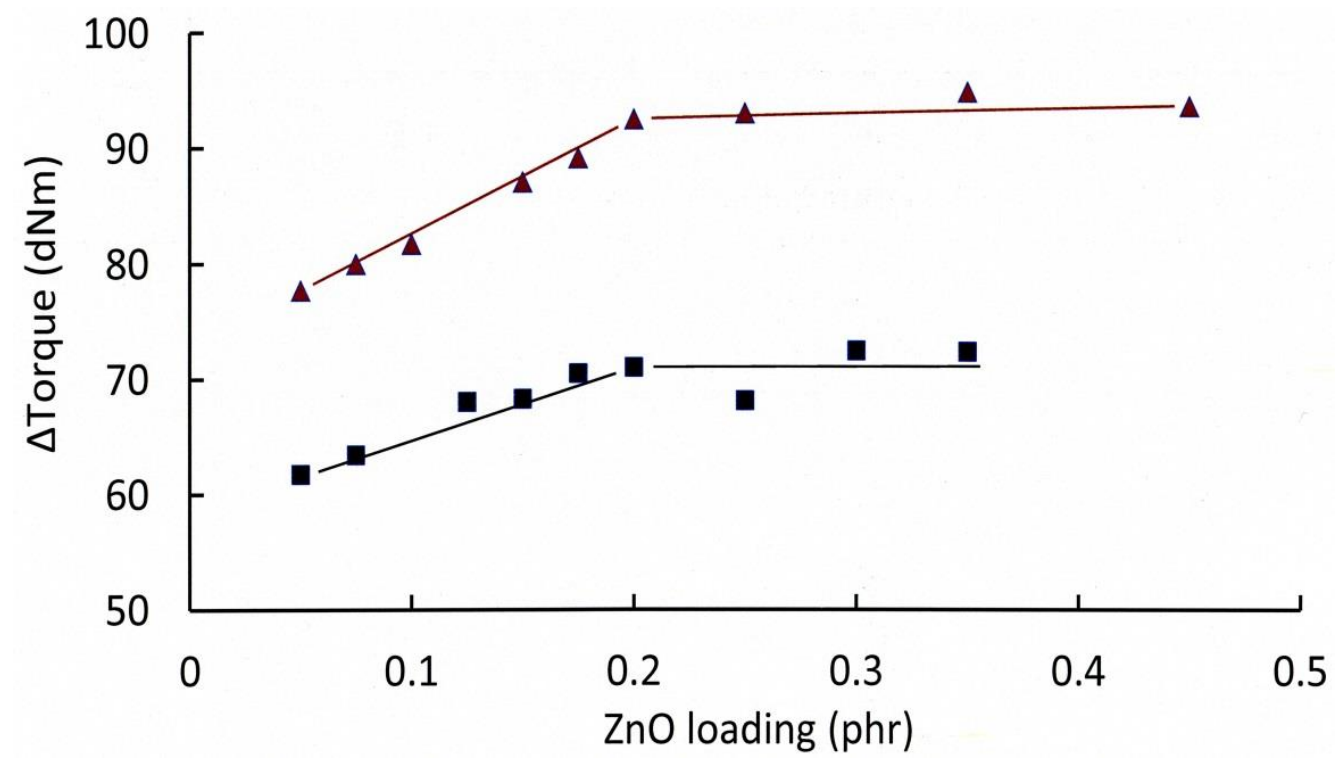

Figure 11. $\Delta$ Torque versus $\mathrm{ZnO}$ loading for the $\mathrm{BR}$ with $0.5 \mathrm{phr}$ sulfur and $1.75 \mathrm{phr}$ TBBS ( $\square)$, BR with 1 phr sulfur and 3 phr TBBS ( $\mathbf{\Delta})$. 


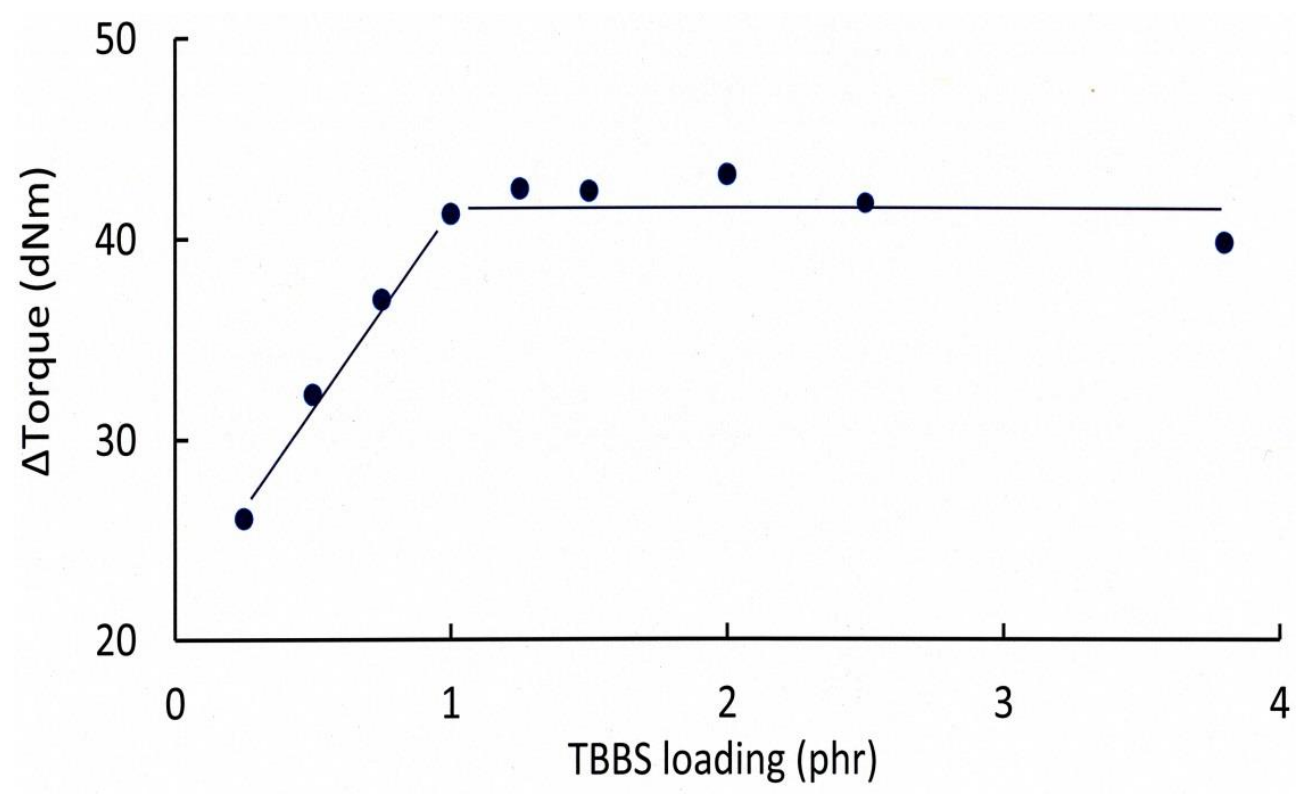

Figure 12. $\triangle$ Torque versus TBBS loading for the EPDM with $1 \mathrm{phr}$ sulfur. 


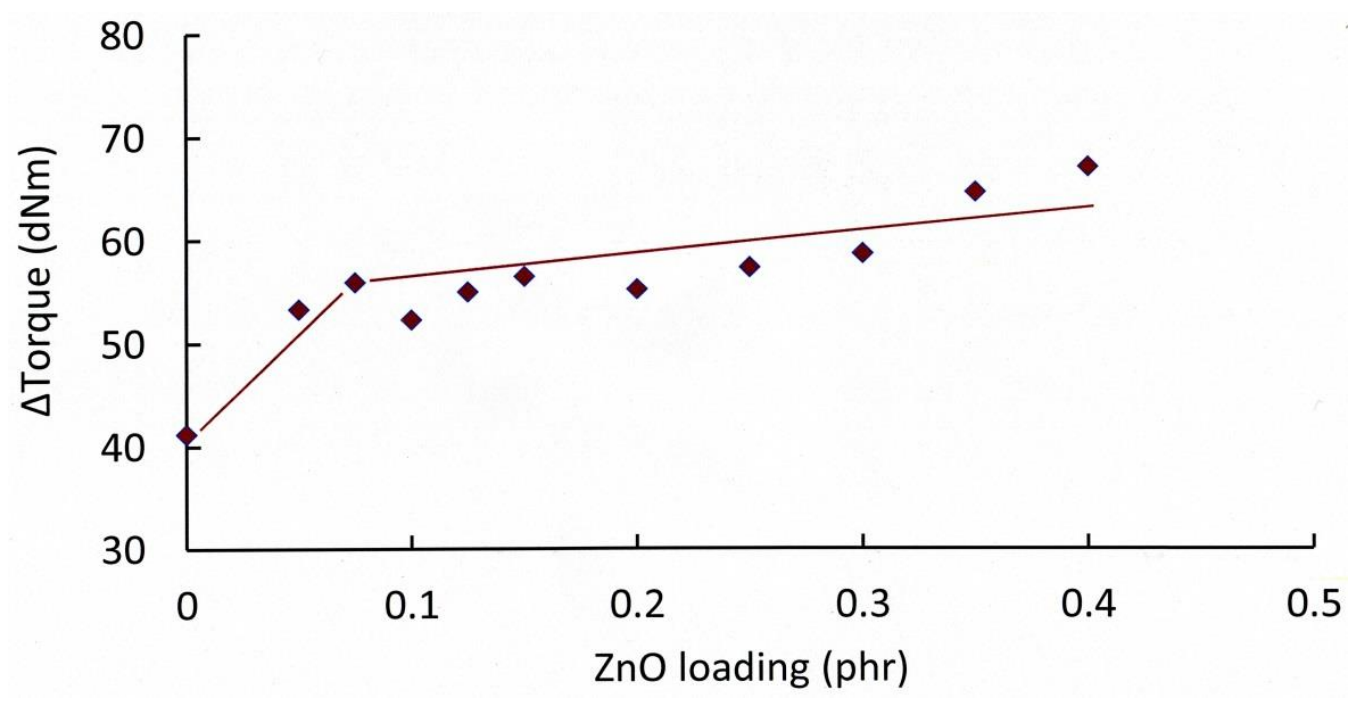

Figure 13. $\Delta$ Torque versus $\mathrm{ZnO}$ loading for the EPDM with $1 \mathrm{phr}$ sulfur and $1 \mathrm{phr}$ TBBS. 


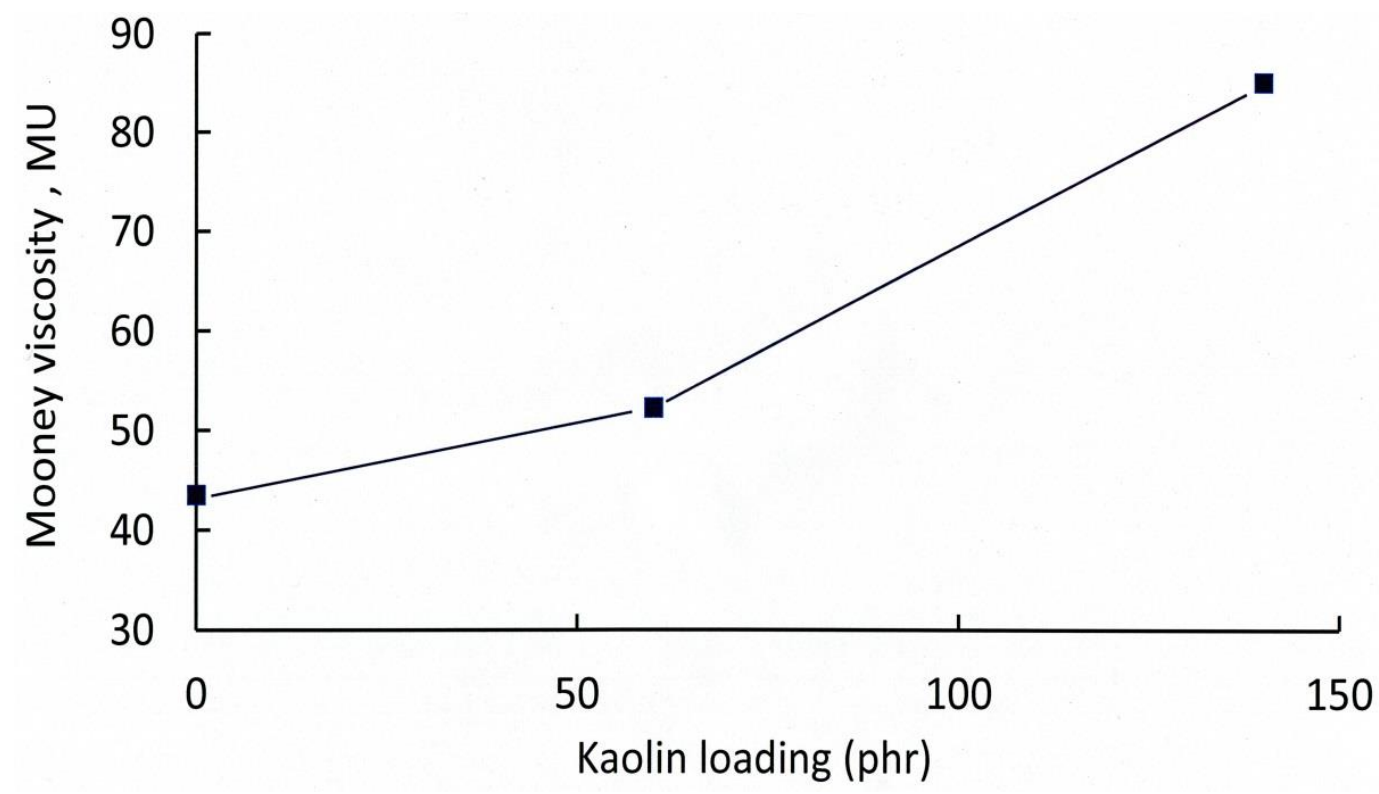

Figure 14. Mooney viscosity versus kaolin loading for composites 1-3 in Table 1. 


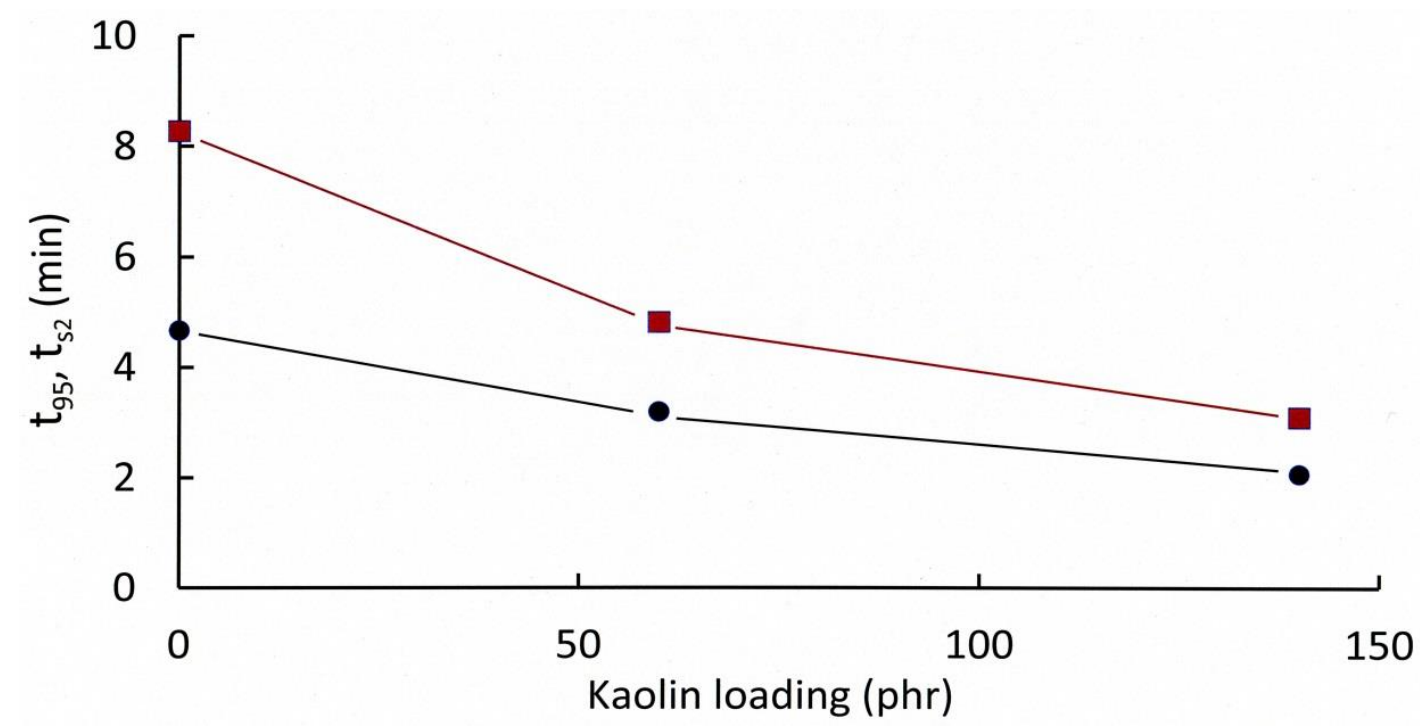

Figure 15. Optimum cure time, $\mathrm{t}_{95}$ and scorch time, $\mathrm{t}_{\mathrm{s} 2}$ versus kaolin loading for composites 1-3 in table 1. Optimum cure time $(\square)$, scorch time $(\bullet)$. 


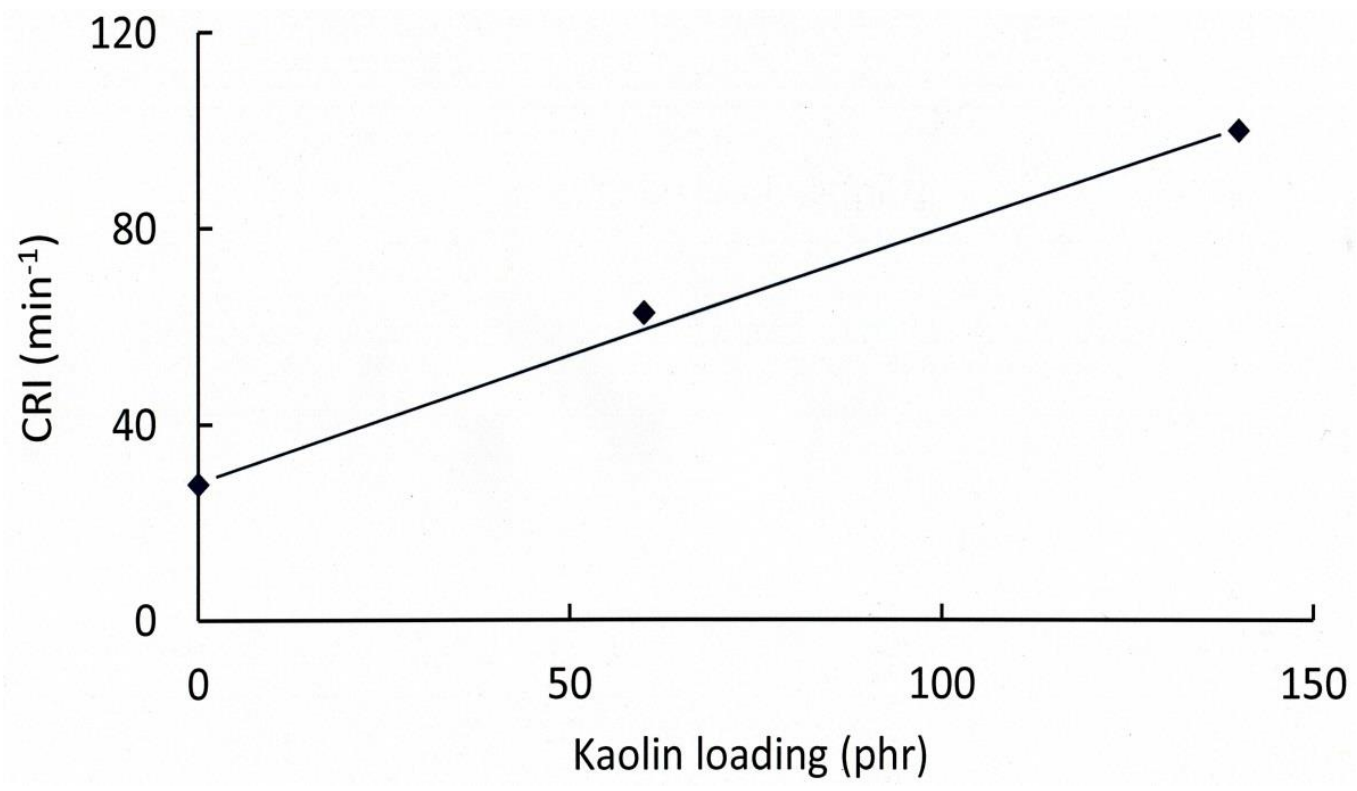

Figure 16. Cure rate index versus kaolin loading for composites 1-3 in Table 1. 


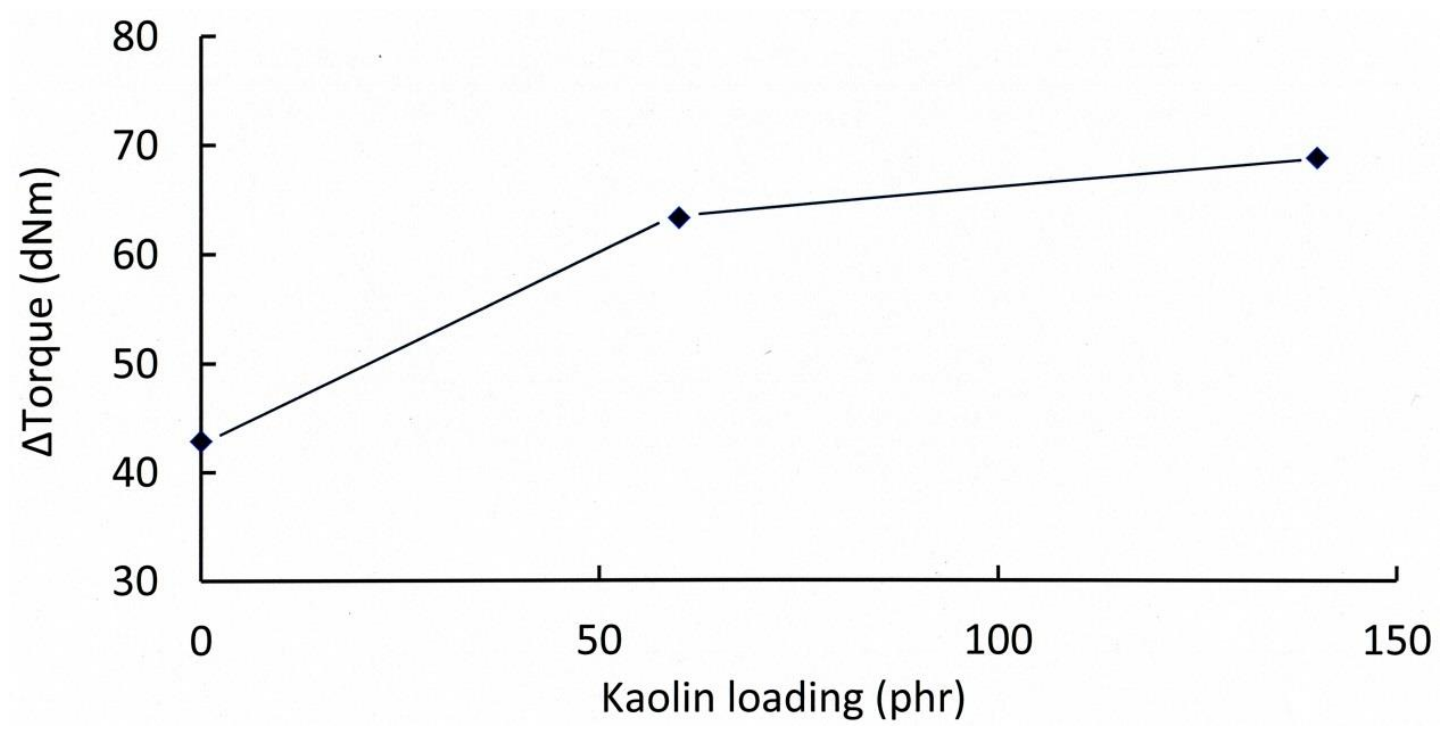

Figure 17. $\Delta$ Torque versus kaolin loading for composites $1-3$ in Table 1. 